\title{
CONSTITUTIONAL RESISTANCE TO EU LAW: THE COURTS AND TEST OF CONSTITUTIONAL IDENTITY CONFLICTS
}

\begin{abstract}
This essay aims to analyze how national constitutional/supreme Courts address the evolution of the European integration process when this latter touches upon fundamental constitutional elements of the EU Member States. More specifically, the paper explores the recent case law concerning the issue of constitutional identity conflicts, in order to show the common arguments underpinning different European constitutional/supreme Courts' jurisprudence. From a comparative point of view, the analysis highlights the emergence of a growing front of constitutional resistance whose meaning for the future of European constitutionalism is still unclear. At the same time, the study seeks to examine the patterns of constitutional resistance within the European integration process in the perspective of a mutual interaction between Courts.
\end{abstract}

Key words: constitutional identity, courts, European constitutionalism, European integration, resistance.

\section{INTRODUCTION}

It is hard to deny that nowadays the European integration project and, in particular, the principle of EU law primacy are navigating turbulent waters. This is especially true, today more than ever, in the wake of the ground-breaking Weiss judgment that the Second Senate of the German Constitutional Court pronounced on the European Central Bank's Public Sector Purchase Program (PSPP) in May 2020. ${ }^{1}$

Stefania Ninatti is full professor of constitutional law, University of Milano Bicocca; e-mail: stefania.ninatti@unimib.it

Marco Galimberti is post-doc researcher in constitutional law, University of Milano Bicocca; e-mail: m.galimberti16@campus.unimib.it

Although this article is the result of a combined and coordinated effort, for purpose of attribution paragraphs 3.2 and 5 were written by Marco Galimberti, paragraphs 2, and 4 by Stefania Ninatti. Introduction, paragraph 3, 3.1 and conclusions were written by both authors.

1 BVerfG, Case No. 2 BvR 859/15, 2 BvR 980/16, 2 BvR 2006/15, 2 BvR 1651/15 of 5 May 2020. 
As the legal scholarship has extensively pointed out, ${ }^{2}$ this momentous decision of the Bundesverfassungsgericht (henceforth BVerfG) is liable to mark a turning point for EU constitutionalism: it poses a serious threat to the safeguard of the unity and integrity of the EU legal order, by setting a dangerous precedent that overwhelms the s.c. "dialogic" relationships between the Court of Justice of the European Union (CJEU) and national constitutional/supreme Courts. Without delving here into the intricate matter of monetary policy and the merits of the ruling at issue - which found both the quantitative easing program and the CJEU's blessing thereof to be "ultra vires"3 -, suffice it to recall that the BVerfG denied to be bound by the earlier judgment of the CJEU and conducted its own review to determine whether the Eurosystem's decisions on the PSPP remain within the competences conferred upon it under EU primary law. ${ }^{4}$

2 For some insightful comments see, among many others, Poiares Maduro, M., 2020, Some Preliminary Remarks on the PSPP Decision of the German Constitutional Court, (https:// https://verfassungsblog.de/some-preliminary-remarks-on-the-pspp-decisionof-the-german-constitutional-court/); Avbelj, M., 2020, The Right Question about the FCC Ultra Vires Decision, (https://verfassungsblog.de/the-right-question-aboutthe-fcc-ultra-vires-decision/); Marzal, T., 2020, Is the BVerfG PSPP decision "simply not comprehensible"?, (https://verfassungsblog.de/is-the-bverfg-pspp-decision-simply-not-comprehensible/); Eleftheriadis, P., 2020, Germany's Failing Court (www. https://verfassungsblog.de/germanys-failing-court/); Garner, O., 2020, Squaring the PSPP Circle, (https://verfassungsblog.de/squaring-the-pspp-circle/); Dyevre, A., 2020, How Europe's Legal Equilibrium Unravelled, (https://ejiltalk.org/how-europes-legal-equilibrium-unravelled/); Caravita, B., Condinanzi, M., Morrone, A., Poggi, A. M., 2020, Karlsruhe: a wrong decision in a difficult political phase, (https://federalismi.it/ nv14/articolo-documento.cfm?hpsez=Primo_Piano\&content=Karlsruhe:-a-wrong-decision-in-a-difficult-political-phase\&content_auth $=\% 253 \mathrm{Cb} \% 253 \mathrm{~EB}$.-Caravita,-M.-Condinanzi,-A.-Morrone,-A.-Poggi\%253C/b\%253E\&Artid=43527); Poli, S., 2020, The German Federal Court and its first ultra vires review: a critique and a preliminary assessment of its consequences, (http://rivista.eurojus.it/the-german-federal-courtand-its-first-ultra-vires-review-a-critique-and-a-preliminary-assessment-of-its-consequences/).

3 In particular, the Second Senate held that the Federal Government and the Bundestag violated the complainants' rights under Art. 38(1) in conjunction with Art. 20(1) and (2), and Art. 79(3) of the Basic Law by failing to take steps challenging that the European Central Bank, in its decisions on the adoption and implementation of the PSPP, neither assessed nor substantiated that the measures provided for in such decisions satisfy the principle of proportionality. Moreover, the Karlsruhe Court found that the CJEU's Weiss judgment of 11 December 2018 on the legality of the ECB's decisions on the PSPP was rendered ultra vires and, therefore, had no legal effect in Germany because it lacks the "minimum of democratic legitimation" necessary under the Basic Law.

4 According to the Second Senate, "Art. 38(1) first sentence in conjunction with Art. 20(1) and (2) first sentence GG affords voters a right vis-à-vis the Federal Government, the Bundestag and, as the case may be, the Bundesrat, compelling these constitutional organs to monitor whether institutions, bodies, offices and agencies of the European Union adhere to the European integration agenda (Integrationsprogramm), to refrain from participating in the adoption and implementation of meas- 
To recall a recent comment of the CJEU president on this judgment, such kind of national constitutional courts intervention sends the critical message "that EU law does not apply with the same force throughout the EU and that 'some Member States are more equal than others"'. ${ }^{\circ}$ As a matter of fact, the Karlsruhe judges did not hesitate to affirm as follows:

"Based on their responsibility with regard to European integration (Integrationsverantwortung), the Federal Government and the German Bundestag have a duty to take active steps against the PSPP given that it constitutes an ultra vires act. [...] German constitutional organs, administrative authorities and courts may participate neither in the development nor in the implementation, execution or operationalisation of ultra vires acts." (paras. 229 and 234).

In view of the foregoing, the case at hand witnesses in an exemplary way a "threatening posture" 6 of the Second Senate's legal reasoning against the supremacy of EU law and, not without a distinctly political accent, its blatant hostility towards the authoritativeness of the Luxembourg Court within the EU legal system. By activating for the first time ever the $u l$ tra vires review of EU measures, which aims to guarantee the democratic principle and is therefore closely interwoven with the protection of German constitutional identity, the BVerfG in fact makes clear that it does not only bark - as it had often done since the early days of the Solange doctrine - but bites as well. ${ }^{7}$

Yet, turning the gaze also towards other Member States' "Europe-related" jurisprudence, one can observe that the Weiss decision is far from being an isolated and completely unpredictable episode. This recent judgment should rather be understood as the latest milestone of a more complex and far-reaching phenomenon of "counter-constitutionalism"

ures that exceed the limits of the integration agenda (Integrationsprogramm), and, where such measures constitute a manifest and structurally significant exceeding of EU competences, to actively take steps to ensure conformity with the integration agenda (Integrationsprogramm) and respect for its limits [...]. The Federal Constitutional Court conducts an ultra vires review to assess whether these standards are met [...]". See BVerfG, Case No. 2 BvR 859/15, 2 BvR 980/16, 2 BvR 2006/15, 2 BvR $1651 / 15$ of 5 May 2020, para. 105 etc.

5 Lenaerts, K., 2020, No Member State is More Equal than Others. The Primacy of EU law and the Principle of the Equality of the Member States before the Treaties, (https:// verfassungsblog.de/no-member-state-is-more-equal-than-others/).

6 This expression is used in Wilkinson, M., 2020, Fight, flight or fudge?, (https://verfassungsblog.de/fight-flight-or-fudge/).

7 Schmid, C., 2001, All Bark and No Bite: Notes on the Federal Constitutional Court's “Banana Decision”, European Law Journal, Vol. 7, No. 1, pp. 95-113.

8 This term is used in Arcari, M., Ninatti, S., Exploring Counter-Constitutionalism: The Backlash Effect of Constitutional Vocabulary of the European Court of Justice and the European Court of Human Rights, paper presented at the GlobCon Scholars 
a paradigm which has increasingly come to the fore, throughout the last decade, alongside the European constitutionalization process. As is wellknown, the constitutional dimension of the European integration has at length been debated by the legal scholars over the years with different perspectives and outcomes.

For their part, the Member States - and more precisely their constitutional/supreme Courts - have shown different possible ways to interact with this kind of evolution and eventually to challenge it. Besides the possibility to declare an EU act as "ultra vires" and, therefore, inconsistent with their domestic constitutions (and the EU Treaties themselves), it has been emerging a second, more refined way to oppose this development, at the core of the constitutional dimension in the making of the EU system: it is rooted in the concept of "constitutional identity", which includes the inalienable respect of some fundamental principles on which the very structure of that State is grounded. It is easy to recognize in this second option some hints of the counter-limits theory developed at the very beginning of the EU integration history by the German and Italian Constitutional Courts. ${ }^{9}$

Following this premise, the aim of the present work is to shed some light on the ever-growing dynamics of constitutional courts' resistance that can be traced in the context of EU law and, as a consequence, to assess its constitutional implications on the European integration process.

Within this framework, a preliminary step focusing on the emergence of constitutional narratives in the EU integration process is needed: constitutional traditions and constitutional identities of the Member States almost naturally took center stage, as we will see, sometimes as a constituent element of such process and sometimes as a counterpart of the ongoing European integration progress. Accordingly, in order to analyze the constitutional components of the EU system, the starting point of the research is the gradual development of the use of the common constitutional traditions as well as the progressive rise of the concept of constitutional identity as a fundamental element of a whole European constituent process up to including in the Lisbon Treaty a specific provision on this matter, i.e. Article 4, 2 TEU (para. 2). ${ }^{10}$ We will then look into a variety of

Workshop, Berlin, 5-6 July 2018, now to be published in: Chiti, E., Martino, A. di, Palombella, G., (eds.), L'età dell'interlegalità, work in progress.

9 For an extensive and thorough analysis of this subject in its entirety see for all Lustig, D., Weiler, J. H. H., 2018, Judicial Review in the Contemporary World - Retrospective and Prospective, International Journal of Constitutional Law, Vol. 16, Issue 2, pp. 315-372.

10 In this perspective, it is to be made immediately clear that this area represents the real battlefield between the national constitutional dimension and the European one: 
reactions by the relevant constitutional/supreme Courts' case law from a comparative perspective, mainly on the side of the "constitutional identity reserve" - even in its close connection with "ultra vires" EU acts review -, thus investigating the patterns of constitutional resistance which can be identified in the European integration process (paras. 3-5).

We will thus examine how the constitutional courts' narrative of resistance reached its (to date) highest peak - or, put differently, its breaking point - with the BVerfG's PSPP decision and whether there were warning signs foreshadowing the perfect storm that has hit the already fragile constitutional equilibrium which underlies the EU legal space in the making. In simpler words, can we detect a fil rouge in the European national constitutional courts case law on these ultimate constitutional conflicts? Do the CJEU and the national constitutional/supreme Courts, walking the tightrope of this trend of judicial "rebellion", manage to settle such conflicts and coexist with each other?

\section{Bits and Pieces of a Constitutional Narrative IN THE EU}

As is well-known, the CJEU never hesitated to define the Treaties as the "basic constitutional charter" of the EU legal order and to recognize its own power of judicial review for EU acts inconsistent with the Treaties. Besides such recognition of the Treaties as the basic charter of the EU, the constitutional narrative in the EU case-law was initially filtered by the introduction of the reference to common constitutional traditions in the CJEU case law. ${ }^{11}$ It is important to start from this point, since it allows us to grasp - from the very beginning - the constitutional interaction shaping the relationship between the EU and the national legal orders.

As a matter of fact, this interpretative canon, when used, provides legal reasoning with a particularly strong and solid foundation, drawing openly on the law of the Member States considered as a whole. The symbolic value of this canon is even more important. Needless to say, the recognition of the European constitutional roots confers a special relevance

even if its borders are still dramatically blurred, this point represents the milestone on which an intertwined paradigm of constitutionalism is currently developing.

11 As is well-known, this latter is an interpretative instrument originally used by CJEU judges (or more frequently by the Advocate General) to fill a gap in the provisions of the Treaties. The judge, by means of this instrument, sounds in depth the national legal principles on the issue at stake in order to distil the European common constitutive notes, which will turn into the so-called general principles of EC law, directly applicable to the case. 
to the criterion in question, since the respect of the diverse Member States' identities, together with the acknowledgment of all that unites them, has always constituted the heart of the community experiment, otherwise known under the saying "united in diversity". ${ }^{12}$

Over time - and even considering the evolution of the EU legal order and the extension of the European territory incorporating political, economic and juridical systems that cannot be entirely ascribed to the history and development of the European integration - the use of the common constitutional traditions canon has not been recessive. And after the issuing of the Charter of Fundamental Rights of the European Union, the common constitutional traditions became the emblem of the s.c. "Europe of rights".

At this point, the narrative on common constitutional traditions starts changing paradigm. It is not the case to recall here the rich CJEU case law on fundamental rights, but the different legal background in which it is now placed has deeply transformed its use: common constitutional traditions begin to fade behind a "clausola di stile" that is tied - together with the reference to the Convention for Human Rights - to the protection of fundamental rights in the EU legal order under Article 6 TEU.

In this shift of the narrative one can begin to grasp the seeds of possible conflicts between the two constitutional dimensions of European integration. Some arguments put forward by the Advocate Generals in delicate cases regarding fundamental rights protected both at national and European level can be helpful in understanding this point.

As a paradigmatic example, the reasoning carried out by Advocate General Poiares Maduro in the well-known Arcelor case highlights the general framework underpinning the said evolution. Letting aside the details of the case, ${ }^{13}$ the question put forward by the French judge to the CJEU

12 In this sense, the rhetoric relating to common constitutional traditions is most certainly very powerful: but, still, it resembles more a "rhetoric" rather than a technical vocabulary, since the choice to use the expression constitutional traditions instead of constitutions immediately proves a wider extension of such legal reasoning (and consequently major creativity by the judge who uses this expression).

13 CJEU, Société Arcelor Atlantique et Lorraine and Others v. Premier ministre, Ministre de l'Ecologie et du Développement durable and Ministre de l'Economie, des Finances et de l'Industrie, Case C-127/07, Opinion of Advocate General Poiares Maduro, 21 May 2008. In a very broad outline, the matter at stake in this case regards the respect of the principle of equality of a French decree implementing an EU directive on the EU Emission Trading Scheme. Starting from the assumption that the principle of equality is also recognized on a community level and as provided by the principle of the separation of the national and EU order, the French Council of State, reviewing the case, decided to refer the question to the CJEU for a preliminary ruling, asking to verify the validity of the directive in the light of the said principle. 
concerns the respect, from the side of an EU act, of the values and constitutional principles of a Member State (more precisely, the equality principle was at stake). This control, however, must be carried out through the recognition of the protection of the same right at a supranational level, as provided by the standards of the common constitutional traditions. Thus, the Council of State requests that the CJEU - when judging the respect of the principle of equality on EU level - takes into consideration the respect of the principle of equality as set down by its own constitution. And it is in this context that the Advocate General makes an interesting suggestion:

"Article 6 TEU expresses the respect due to national constitutional values. It also indicates how best to prevent any real conflict with them, in particular by anchoring the constitutional foundations of the European Union in the constitutional principles common to the Member States. Through this provision the Member States are reassured that the law of the European Union will not threaten the fundamental values of their constitutions. At the same time, however, they have transferred to the CJEU the task of protecting those values within the scope of Community law. In that connection, the Conseil d'Etat is correct in assuming that the fundamental values of its constitution and those of the Community legal order are identical. It must be pointed out, however, that that structural congruence can be guaranteed only organically and only at the Community level, through the mechanisms provided for by the Treaty. It is that organic identity which is referred to in Article 6 TEU and which ensures that national constitutions are not undermined, even though they can no longer be used as points of reference for the purpose of reviewing the lawfulness of Community acts." (para. 16).

On the basis of these statements we can incidentally infer that the criterion of the common constitutional traditions is beginning to shift from its own territory of an interpretative canon, rooted in the different expressions of the Member States' constitutional orders, to a sort of founding principle of the common values of the European Union. The common constitutional traditions affecting separately and over time the EU legal order are now transformed in a sort of "European tradition" that is reshaping values and rights of EU countries. In this reconstruction it is obvious that the national Supreme Courts should cooperate in close connection (or dialogue) with the CJEU by means of the preliminary reference in order to steadily deepen this common tradition.

Echoes of this understanding could be traced in one of the first and most famous cases regarding a constitutional conflict between a national Constitutional Court and the Luxembourg Court. As is well-known, the Melloni case ${ }^{14}$ deals with the procedures provided for by the European

14 CJEU, Stefano Melloni v. Ministerio Fiscal, Case C-399/11, 26 February 2013. See also the Opinion of Advocate General Bot delivered on 2 October 2012. 
Arrest Warrant and has its origin in the Spanish case-law of the Tribunal Constitucional, according to which the execution of a European arrest warrant must be subject to certain conditions (not foreseen in the EU regulation), that would set a higher standard of protection for the convicted person. ${ }^{15}$

Interestingly enough, the CJEU states that it is not necessary to analyze the constitutional traditions of the Member States once the EU Council Framework Agreement at stake has been adopted. In this occasion, the Advocate General observed - by and large - that "a concept demanding protection for a fundamental right must not be confused with an attack on the national identity or, more specifically, the constitutional identity of a Member State" (para. 142, referring to Art. 4, 2, TEU).

On this last issue, we have to recall that the Lisbon Treaty introduced a new provision compelling the EU to respect the national identity of the Member States, i.e. "their fundamental structures, political and constitutional structure". ${ }^{16}$ If one can read this article as a clear limit to the expansive attitude of the European Union system, some legal scholars have properly observed that it can also be interpreted in another way: absorbing the national identity's protection in the very fabric of the EU Treaties could end up in transposing its control at the EU level. This latter reading could actually be confirmed by the direction undertaken in the EU case law regarding the common constitutional traditions.

That being said, there is a small note to add at this point: taking for granted (or absorbed within the EU system) common constitutional traditions and constitutional identity - as they evolve with the passing of time - could be a risky choice from the point of view of acceptance of the CJEU case law in the national legal frameworks.

15 Again, the words of Advocate General Bot may help us to frame the issue at stake: "[...] the Court of Justice cannot rely on the constitutional traditions common to the Member States in order to apply a higher level of protection. Indeed, the fact that Framework Decision 2009/299 is the result of an initiative by seven Member States and that it has been adopted by all the Member States allows us to presume, with sufficient certainty, that a large majority of the Member States do not share the view taken by the Tribunal Constitucional in its case-law." (para. 84).

16 More precisely, Art. 4(2) TEU states that "The Union shall respect the equality of Member States before the Treaties as well as their national identities, inherent in their fundamental structures, political and constitutional, inclusive of regional and local self-government. It shall respect their essential State functions, including ensuring the territorial integrity of the State, maintaining law and order and safeguarding national security. In particular, national security remains the sole responsibility of each Member State." See also Art. 6(3) TEU when it states that "Fundamental rights, as guaranteed by the European Convention for the Protection of Human Rights and Fundamental Freedoms and as they result from the constitutional traditions common to the Member States, shall constitute general principles of the Union's law". 
This issue is actually at stake in one of the case studies we are going to deal with in our analysis. In Gauweiler the Advocate General pointed out very clearly the possible paradox arising from the separation of the two constitutional poles of the European integration:

"I think it is useful to recall that the Court of Justice has long worked with the category of 'constitutional traditions common' to the Member States when seeking guidelines on which to construct the system of values on which the Union is based. Specifically, the Court of Justice has given preference to those constitutional traditions when establishing a particular culture of rights, namely that of the Union. The Union has thus acquired the character, not just of a community governed by the rule of law, but also of a 'community imbued with a constitutional culture'. That common constitutional culture can be seen as part of the common identity of the Union, with the important consequence, to my mind, that the constitutional identity of each Member State, which of course is specific to the extent necessary, cannot be regarded, to state matters cautiously, as light years away from that common constitutional culture. Rather, a clearly understood, open, attitude to EU law should in the medium and long term give rise, as a principle, to basic convergence between the constitutional identity of the Union and that of each of the Member States." (para. 61). ${ }^{17}$

\section{A Counter-Narrative: How Constitutional COURTS REACT}

The reactions of the domestic constitutional courts to this trend, as we have already mentioned, share a common reflection, even though they bear different tones: a renewed call for the respect of competences and for the safeguard of national identity, together with a general fear of a further overstretching of the EU's powers. Transgression of competences (ultra vires act review) and violation of constitutional identity (identity review)

17 CJEU, Peter Gauweiler and Others v. Deutscher Bundestag, Case C-62/14, Opinion of Advocate General Cruz Villalón, 14 January 2015. The previous paragraphs (59-60) are also very interesting: "The first is that it seems to me an all but impossible task to preserve this Union, as we know it today, if it is to be made subject to an absolute reservation, ill-defined and virtually at the discretion of each of the Member States, which takes the form of a category described as 'constitutional identity'. That is particularly the case if that 'constitutional identity' is stated to be different from the 'national identity' referred to in Article 4(2) TEU. Such a 'reservation of identity', independently formed and interpreted by the competent — often judicial — bodies of the Member States would very probably leave the EU legal order in a subordinate position, at least in qualitative terms. Without going into details, and without seeking to pass judgment, I think that the characteristics of the case before us may provide a good illustration of the scenario I have just outlined." 
constitute the two mainstreams polarizing the front of resistance of the national Constitutional and Supreme Courts.

In the following pages, we will mainly focus our attention on the identity review since it can better convey the message of constitutional resistance, even if both these reviews concur to shape the borders thereof and are often considered together. ${ }^{18}$ More specifically, to borrow the words of the German Bundesverfassungsgericht: "both the identity review and the ultra vires review are derived from Art. 79 sec. 3 GG but constitute independent types of review using different standards". Furthermore, the Karlsruhe judges highlighted that "the competence retained by the Court for both of these reviews must be exercised cautiously and in a way that is open to European integration (europarechtsfreundlich)". ${ }^{19}$

To be precise, the choice to add the category of constitutional identity review to the already existing ultra vires act review is in itself part and parcel of the sui generis European constitutional narrative. While an ultra vires act always implies a defect in the act from the competence's point of view and, therefore, a possible declaration concerning the validity and/or the application of European law in all other Member States, a violation of constitutional identity works in a totally different way: as a matter of fact, this scrutiny is based on a "bipolar relationship" between one Member State and the EU and rests inevitably on a "joint effort of national and European courts". ${ }^{20}$

\subsection{THE LISSABON-URTEIL: WHERE IDENTITY REVIEW BEGINS}

As a premise, before entering into the details of the more recent cases involving a dialogue with the European counterpart, it is important to recall that the key position acquired by the constitutional identity review was actually launched in the landmark judgment Lissabon-Urteil of the

18 BVerfG, Case No. 2 BvR 2728/13 of 14 January 2014, para. 61.

19 Ibid., para. 121. More specifically, see also para. 153, where the constitutional court highlights that the control of constitutional identity and control over ultra vires acts are both founded on Art. 79, 3, GG, but they are autonomous and distinct constitutional remedies. The judgment gives the opportunity to explain more clearly that "the ultra vires review constitutes a particular case [...] of the application of the general protection of the constitutional identity by the Federal Constitutional Court. When conducting ultra vires review, the Federal Constitutional Court examines whether EU acts transgress the competences' boundaries. Considering that these latter can be transferred to the EU only within the limits set by Art. 79 sec. 3 GG, the ultra vires review is without fail joined by the identity review [...]. Unlike the ultra vires review, the identity review "examines the respective act of the European Union in a substantive sense as to whether the "ultimate limit" of the principles of Arts. 1 and 2 GG has been exceeded [...]."

20 Mayer, F. C., 2014, Rebels Without a Cause? A Critical Analysis of the German Constitutional Court's OMT Reference, German Law Journal, Vol. 15, p. 133. 
BVerfG, concerning the compatibility of the new Lisbon Treaty with the German Constitution. As is well-known, before this historical decision, the BVerfG's control over EU law was limited to the ultra vires review (Maastricht decision of 1993).

It should be noticed that the concept of constitutional identity did not arise out of the blue in the Lissabon-Urteil. In fact, the BVerfG had already sowed the seeds of the Verfassungsidentität in its Solange II decision (1986), which pointed at constitutional identity as "the fundamental architecture, the constitutive structures" of the German Basic Law (Grundgesetz). ${ }^{21}$ Interestingly enough, the Karlsruhe Court buttressed this statement by means of an explicit reference to the "similar limits" set under the Italian Constitution and constitutional jurisprudence, ${ }^{22}$ which had in turn construed the fundamental principles of the national constitutional order as a sort of red line that Community law must not dare to overstep in any way whatsoever.

Such identity clause in the making, to which both the BVerfG and the Italian Corte Costituzionale opened up their counter-limits doctrines originally grounded on fundamental rights protection, sounded thenceforth as a siren call for the constitutional jurisdictions of other EU Member States. For instance, in 2004 the French Constitutional Council first acknowledged constitutional identity as a limitation to the principle of unconditional primacy (and, thus, to the internal application) of EU legislation staunchly advocated by the CJEU case law. ${ }^{23}$ Shortly thereafter, in opinion n. 1/2004 on the constitutional legitimacy of the European

21 BVerfG, Case No. 2 BvR 197/83 of 22 October 1986, para. 375 etc. With regard to this point, see Mayer, F. C., 2011, Rashomon in Karlsruhe: A reflection on democracy and identity in the European Union: The German Constitutional Court's Lisbon decision and the changing landscape of European constitutionalism, International Journal of Constitutional Law, Vol. 9, Issue 3-4, pp. 781-782.

22 In this respect, Solange II judgment expressly recalled the contribution by La Pergola, A., Del Duca, P., 1985, Community Law and the Italian Constitution, American Journal of International Law, Vol. 79, Issue 3, pp. 598-621. Moreover, such horizontal connection between Rome and Karlsruhe can be identified in BVerfG, Case No. 2 BvL 52/71 of 29 May 1974 (Solange I), where three dissenting judges quoted the Frontini decision the Italian Constitutional Court had delivered just one year earlier (Judgment No. 183/1973).

23 Among others, see Conseil Constitutionnel, Traité établissant une Constitution pour l'Europe, Judgment no. 2004-505 DC of 19 November 2004 (https://conseil-constitutionnel.fr/decision/2004/2004505DC.htm). Less than two years later, in Conseil Constitutionnel, Loi relative au droit d'auteur et aux droits voisins dans la société de l'information, Judgment no. 2006-540 DC of 27 June 2006, para. 19 (https://conseil-constitutionnel.fr/decision/2006/2006540DC.htm), the Constitutional Council made clear that, although the execution of Union law is for French authorities a constitutional duty based on Article 88-1 of the Constitution, "the transposition of 
Constitutional Treaty, the Spanish Constitutional Tribunal hinted at the former jurisprudence of several other Constitutional Courts which had raised reservations against the precedence of EU law over their national constitutions. ${ }^{24}$ According to the Tribunal Constitucional, those boundaries were echoed in the Constitutional Treaty itself, whose Art. I-5 - by adopting an expression now reflected in Art. 4(2) TEU - provided that "the Union shall respect the national identities of the Member States inherent in their fundamental structures, political and constitutional". 25

By the same token, a comparable approach can also be found in the case law of younger Constitutional Courts based in Central and Eastern Europe. ${ }^{26}$ In this context, the joint reading of two judgments the Polish Constitutional Tribunal delivered in 2005 - as concerns, respectively, the law transposing the Framework Decision on the European Arrest Warrant ${ }^{27}$ and the conformity of the Accession Treaty with the Constitution

a Directive cannot run counter to a rule or principle inherent to the constitutional identity of France, except when the constituting power consents thereto".

24 Tribunal Constitucional, Declaration No. 1/2004 of 13 December 2004 (https://hj.tribunalconstitucional.es/en/Resolucion/Show/6945), Grounds of the judgment, para. 3: "the lack of such a guarantee [of the existence of Member States, their essential structures, as well as their values, principles and fundamental rights...] or the lack of its explicit proclamation, justified in previous times the reserve against the primacy of Community legislation over national constitutions by well-known decisions of the constitutional courts of several Member States, in the so-called doctrine of dialogue between constitutional courts and the Court of Justice of the European Union".

25 Ibid., the Tribunal Constitucional stated that "the limits referred to by the reservations of said constitutional justifications now appear proclaimed in an unequivocal way by the Constitutional Treaty, which has adapted its provisions to the requirements of the constitutions of the Member States. Therefore, the primacy proclaimed in the Constitutional Treaty operates in the context of a legal order which is built upon values common to the constitutions of the states integrated into the Union and their constitutional traditions."

26 Even though the scope of the present analysis does not allow to go into the details of the activism characterizing these jurisdictions, it is useful to bear in mind that, quoting the words of Sadurski, "one of the most striking features of the ongoing transitions to democracy in these societies is the spectacular growth in the role and prominence of constitutional courts and tribunals in shaping the new constitutional order". Furthermore, according to Habermas, in Central and Eastern European legal frameworks "there is noticeably little enthusiasm for the transfer of the recently won rights of sovereignty to European level". See Sadurski, W., Constitutional Justice, East and West: Introduction, in: Sadurski, W., 2002, Constitutional Justice, East and West: Democratic Legitimacy and Constitutional Courts in Post-Communist Europe in a Comparative Perspective, The Hague, Kluwer, p. 1; Habermas, J., 2001, So, Why Does Europe Need a Constitution?, Florence, European University Institute, Robert Schuman Centre of Advanced Studies, p. 7.

27 Trybunal Konstytucyjny, Judgment P 1/05 of 27 April 2005. For a comparative analysis between the Polish case and the similar constitutional challenges being faced 
of Poland ${ }^{28}$ - suggests that neither the establishment of an European area of freedom, security and justice nor the membership of the EU may challenge the constitutional identity of the Member States. Just a few days later, the Constitutional Court of Hungary quashed a parliamentary act intended to implement two European regulations on measures regarding agricultural surplus stocks ${ }^{29}$ for breaching the principle of rule of law and for being contrary to the requirement of legal certainty, which are both cornerstones of the national constitutional identity. ${ }^{30}$ Similarly, in 2006 the Czech Constitutional Court made clear that it would be "called upon to protect constitutionalism" and to exercise constitutional review if EU law threatened the foundations of state sovereignty and the Constitution's basic principles which cannot be subject to revision. ${ }^{31}$

meanwhile in other Member States, see Pollicino, O., 2008, European Arrest Warrant and Constitutional Principles of the Member States: a Case Law-Based Outline in the Attempt to Strike the Right Balance between Interacting Legal Systems, German Law Journal, Vol. 9, No. 1, p. 1330.

28 Trybunal Konstytucyjny, Judgment K 18/04 of 11 May 2005. See especially at paras. 13-14: "a collision [between Community norms and the Polish Constitution] may in no event be resolved by assuming the supremacy of a Community norm over a constitutional norm. Furthermore, it may not lead to the situation whereby a constitutional norm loses its binding force and is substituted by a Community norm, nor may it lead to the application of the constitutional norm to restricted to areas beyond the scope of Community law regulation. In such an event the Nation as the sovereign [...] would need to decide on: amending the Constitution; or causing modifications within Community provisions; or, ultimately, on Poland's withdrawal from the European law [...].

The principle of interpreting domestic law in a manner 'sympathetic to European law' [...] has its limits. In no event may it lead to results contradicting the explicit wording of constitutional norms or being irreconcilable with the minimum guarantee functions realized by the Constitution. In particular, the norms of the Constitution within the field of individual rights and freedoms indicate a minimum and unsurpassable threshold which may not be lowered or questioned as a result of the introduction of Community provisions."

29 The Surplus Act aimed at transposing into Hungarian law the Commission Regulation 1972/2003/EC of 10 November 2003 on transitional measures to be adopted in respect of trade in agricultural products and the Commission Regulation 60/2004/EC of 14 January 2004 laying down transitional measures in the sugar sector on account of the accession of the Czech Republic, Estonia, Cyprus, Latvia, Lithuania, Hungary, Malta, Poland, Slovenia and Slovakia.

30 Alkotmánybíróság, Decision AB 17/04 of 25 May 2005. For a comment, see Sajo, A., 2004, Learning Co-operative Constitutionalism in the Hard Way: the Hungarian Constitutional Court Shying Away from EU Supremacy, in Zeitschrift für Staats- und Europawissenschaften, Vol. 2, Issue 3, pp. 351-371.

31 Particularly, constitutional review of EU law relies on Article 9(2) of the Czech Constitution, which stipulates that "the substantive requisites of the democratic, law-abiding State may not be amended”. See Ústavni Soúd, Decision Pl. ÚS 50/04 (Sugar Quotas) of 8 March 2006, para. VI.A.-3. The English translation is available at https://usoud.cz/en/decisions. 
Against this background of an ever increasing horizontal cohesion, ${ }^{32}$ the identity-based avenue of constitutional resistance vis-à-vis any potential encroachment on the very essence of national sovereignty becomes all the more central - and in a certain sense paradigmatic also for other European constitutional courts ${ }^{33}$ - in the German decision concerning the constitutionality of the Lisbon Treaty.

Borrowing the words of the Lissabon-Urteil, ${ }^{34}$ the German constitutional judge is entitled to review

"whether the inviolable core content of the constitutional identity of the Ba-
sic Law pursuant to Article 23.1 third sentence in conjunction with Article
79.3 of the Basic Law is respected. The exercise of this review power, which
is rooted in constitutional law, follows the principle of the Basic Law's
openness towards European Law (Europarechtsfreundlichkeit), and it the-
refore also does not contradict the principle of sincere cooperation (Article
4.3 Lisbon TEU); otherwise, with progressing integration, the fundamental
political and constitutional structures of sovereign Member States, which
are recognised by Article 4.2 first sentence Lisbon TEU, cannot be safeguar-
ded in any other way. In this respect, the guarantee of national constitutio-
nal identity under constitutional and under Union law go hand in hand in
the European legal area. The identity review makes it possible to examine
whether due to the action of European institutions, the principles under
Article 1 and Article 20 of the Basic Law, declared inviolable in Article
79.3 of the Basic Law, have been violated. This ensures that the primacy
of application of Union law only applies by virtue and in the context of the
constitutional empowerment that continues in effect." (para. 240).

The new frontier of the well-known counter-limits theory assumes now the shape of the constitutional identity clause, thus expanding the competences of the Constitutional Court from the realm of fundamental rights to other essential issues pertaining the core of the State. In an exemplary way, the judgment at hand bluntly remarks also that there are five fundamental areas of law that have to remain close to the citizen and that directly shape the form of a constitutional State. ${ }^{35}$ By and large, we could say that consti-

32 In regard to this, the Czech Constitutional Court pointed out that "several high courts of older Member States [...] have never entirely acquiesced in the doctrine of the absolute precedence of Community law over the entirety of constitutional law; first and foremost, they retained a certain reserve to interpret principles such as the democratic law-based state and the protection of fundamental rights". Ibid., para. VI.A.

33 On the possible influence exercised also by the German Constitutional Court in Europe see the various essays of the symposium German Legal Hegemony?, 2020, (https://verfassungsblog.de/category/debates/german-legal-hegemony-debates/).

34 BVerfG, 2 BvE 2/08, 2 BvE 5/08, 2 BvR 1010/08, 2 BvR 1022/08, 2 BvR 1259/08, 2 BvR 182/09 of 30 June 2009.

35 This worry can be traced in many passages of the Lissabon-Urteil. See in an exemplary way, besides para. 249, para. 252: "Particularly sensitive for the ability of a constitu- 
tutional identity requires sovereignty of States both under international law and under constitutional law (i.e. an independent political community ruled by the democratic principle and with budgetary powers). ${ }^{36}$

$\mathrm{Be}$ it as it may, in this judgment the BVerfG confirms itself as the ultimate arbiter, i.e. the guardian of the constitution, thus strengthening the judicial review conducted by constitutional courts. Indeed, the German Bundesverfassungsgericht even provides that, along with the progress of integration, the identity review can become increasingly important and hopes for the creation of a special procedure by the German legislator to carry out this control (paras. 240-241).

The reference to the s.c. Ewigkeitsklausel (eternity clause, ex art. 79.3 GG in connection with Art. 1 and 20 GG) is actually very important to start drawing the outline of constitutional resistance in Europe. The reader could be puzzled by the fact that the boundaries set for the EU integration are the same recognized for the domestic constitutional reform. For many good reasons.

First, according to this reading the European integration falls within the borders of the s.c. "poivoir constituent dérive" and cannot go beyond that. It is, after all, a bold statement - maybe even just another version of the dualist reading of the relationship between the two orders - since it places the origin of the constituent power of the European integration strictly within the framework of the domestic (German) constitutions or, at least, it seems to subject the European integration to the conditions posed by the eternity clause. By the way, if we look at this statement from the EU perspective, the autonomy of the EU system is seriously questioned.

Second, as Cassese critically observed, placing this clause - originally born in a strictly national environment - in a multilevel context is a kind of functional distortion. As is well-known, the limits to constitutional reform were conceived in order to prevent any return to the dictatorship. On the contrary, here it is used to preserve the sovereignty of the German state and to prevent future further developments of the European Union,

tional state to democratically shape itself are decisions on substantive and formal criminal law (1), on the disposition of the monopoly on the use of force by the police within the state and by the military towards the exterior (2), fundamental fiscal decisions on public revenue and public expenditure, the latter being particularly motivated, inter alia, by social policy considerations (3), decisions on the shaping of living conditions in a social state (4) and decisions of particular cultural importance, for example on family law, the school and education system and on dealing with religious communities (5)."

36 See Claes, M., Reestman, J. H., 2015, The Protection of National Constitutional Identity and the Limits of European Integration at the Occasion of the Gauweiler Case, German Law Journal, Vol. 16, Issue 4, p. 923, where they recognize as well that "here and there some elements of it lighten up, but much remains in the dark". 
that institution which was also set up precisely to prevent the return to dictatorships and European wars. ${ }^{37}$ Strange but true.

Third, we could assume that the identity review is a kind of "counter-limits theory 2.0", that includes more generally the core element of a constitutional state and not just a catalogue of fundamental rights. Still, limits to constitutional reforms and counter-limits to the EU and international law are born in such a different context that it appears not possible just to merge them into each other. In this sense, it has been observed that also from a procedural point of view the identity review does not represent a kind of "wider" counter-limit, but a constitutional standard used to measure the consistency of the EU legal order with the German constitution. ${ }^{38}$ It is not yet clear, though, what the potential legal consequences are of a judgment of this kind. Be as it may, we are dealing here with a kind of review which goes beyond the check of the respect for fundamental constitutional principles (understood as counter-limits) and which goes beyond the three judgments known as Solange I, Solange II and Maastricht-Urteil as well.

Last but not least - always aiming to show some traits of constitutional resistance - this kind of judgment often takes the appearance of a "sentenza-manifesto politico", 39 instead of a traditional decision with concrete and immediate legal consequences. It can be read as a warning for EU institutions as well as for the national legislature. And certainly, this kind of judgment conveys a message for the domestic ordinary judges, forcing them in these cases to call into question the Constitutional Court. Although the legal scholarship has already written extensively on this judgment, it is worth considering that authoritative scholars acknowledged in this statement the move from a "defensive constitutional pluralism" (in the age of the counter-limits theory) to an "aggressive constitutional pluralism". ${ }^{40}$

\subsection{BEYOND THE NATIONAL BORDERS: THE HORIZONTAL MIGRATION OF IDENTITY REVIEW}

The analysis of the Lissabon-Urteil offers the opportunity to extend the scope of our study to a further, though still largely unexplored, dimension of European constitutional law. As a matter of fact, this seminal ruling of the BVerfG on the constitutional legitimacy of the Lisbon Treaty

37 Cassese, S., 2009, L’Unione europea e il guinzaglio tedesco, Giornale di diritto amministrativo, 9, p. 1004.

38 For all, see Chiti, M. P., 2009, Am deutschen Volk, Giornale di diritto amministrativo, 9, p. 1011.

39 Ibid., p. 1003.

40 Poiares Maduro, M., Grasso, G., 2009, Quale Europa dopo la sentenza della Corte costituzionale tedesca sul Trattato di Lisbona?, Diritto dell'Unione Europea, 2, p. 527. 
allows to shift from the "vertical" perspective examined thus far, i.e. the relationship between the Luxembourg Court and the domestic constitutional jurisdictions, to a s.c. "horizontal" dimension of the national constitutional courts case law themself.41

Looking at this judgment of the German Constitutional Court through the lens of comparative reasoning, can the concept of "Identitätskontrolle" carved out therein also be detected, mutatis mutandis, across the Lisbon case law of the French Conseil Constitutionnel, the Czech Constitutional Court and the Polish Constitutional Tribunal? ${ }^{42}$ To what extent does the German model substantively match the understandings of constitutional identity that surfaced, meanwhile, in the foreign Lisbon-related jurisprudence?

By starting from the French case, the Conseil Constitutionnel first and foremost made clear that primary EU law must neither contain "a clause running counter to the Constitution", call into question constitutionally guaranteed rights and freedoms, nor must it "adversely affect the essential conditions of the exercise of national sovereignty", unless the Constitution is revised beforehand. ${ }^{43}$ Between the lines of the French Lisbon ruling, even without being mentioned directly, constitutional identity looms, therefore,

41 With regard to this horizontal perspective, the analysis of which falls beyond the scope of the present work, it is worth mentioning the case law concerning the constitutional legitimacy of the Maastricht Treaty. As is well-known, several constitutional jurisdictions, such as the Danish Supreme Court, followed in the footsteps of the German Maastricht-Urteil in order to claim power to scrutinize whether an act of EU law exceeds the competences conferred upon the European institutions or not. For a comparative overview see Baquero Cruz, J., 2008, The Legacy of the Maastricht-Urteil and the Pluralist Movement, European Law Journal, Vol. 14, No. 4, pp. 389-422, where the Maastricht Urteil is defined as "a symbol, a catalyst and an incentive in other Member States".

42 In addition to the Lisbon rulings compared hereinafter, see also the Lisbon Treaty decision of the Austrian Verfassungsgerichtshof, SV 2/08, G 80/08, 30 September 2008; Judgment 2008-35-01 of 7 April 2009, Treaty of Lisbon, given by the Latvian Satversmes Tiesa; the Lisszabon Decision 143/2010 (VII. 14.) rendered by the Hungarian Alkotmánybíróság on 12 July 2010.

43 Conseil Constitutionnel, Treaty of Lisbon amending the Treaty on European Union and the Treaty establishing the European Community, Decision 2007-560 of 20 December 2007, para. 9 (English translation available at https://conseil-constitutionnel.fr/ en/decision/2007/2007560DC.htm). In harmony with the Conseil's previous case law, para. 18 of this judgment reiterated that the treaty provisions requiring prior revision of the Constitution are the ones which transfer fields of competences being "inherent to national sovereignty", such as the fight against terrorism and related activities, border controls, fight against trafficking in human beings, judicial cooperation on civil matters and in criminal matters. Furthermore, at para. 20 of the Lisbon decision the Conseil added that in fields of competences already transferred to the EU, but which are "inherent" to national sovereignty, any modification of the EU rules on decision-making requires amendments of the Constitution. See Vranes, E., 2013, Con- 
as a boundary to the European integration process. Yet, such boundary confining the primacy of EU law is not designed as an insurmountable frontier: it can be overcome through a constitutional adjustment which, most importantly, is not subject to the Constitutional Council's review. Moreover, this judicial self-restraint of the Conseil Constitutionnel is confirmed by the fact that it avoided to point out which principles would concretely fall within the notion and the scope of constitutional identity. This implies that, in contrast to the reaction of their German counterparts, the French judges accorded the legislature a higher degree of deference to set identity-based limitations to further European integration. ${ }^{44}$

A position that, in some respects, resembles the stance taken by the Conseil Constitutionnel can be recognized in the case law of the Czech Constitutional Court (Ústavni Soúd). In finding the contested treaty provisions to be compatible with the national constitution, the first Lisbon ruling of the Ustavni Soúd (2008) maintained that substantive limits to the transfer of sovereignty

"should be left primarily to the legislature to specify, because this is a priori a political question, which provides the legislature wide discretion; interference by the Constitutional Court should come into consideration as ultima ratio." (para. 109). ${ }^{45}$

Accordingly, in response to a second petition regarding the constitutionality of the Lisbon Treaty (2009), the Czech justices bluntly distanced themselves from the BVerfG's activist approach to constitutional identity. ${ }^{46}$ In open defiance of the Lissabon-Urteil, the Ustavni Soúd rejected the demand to draw up a catalogue of material competences that the State

stitutional Foundation of, and Limitation to, Integration in France, European Public Law, Vol. 17, No. 3, pp. 541-542.

44 For an in-depth comparison between the French Lisbon decision and the Lissabon-Urteil, especially from the perspective of constitutional identity, see Reestman, J. H., 2009, The Franco-German Constitutional Divide: Reflection on National and Constitutional Identity, European Constitutional Law Review, Vol. 5, Issue 3, pp. 374-390.

45 Ústavni Soúd, PI. ÚS 19/08, Judgment of 26 November 2008 (Treaty of Lisbon I). An English translation of this decision is available at https://usoud.cz/en/decisions. Interestingly enough, from a horizontal perspective the Brno Court, which is admittedly reminiscent of "certain important decisions of other constitutional courts", noticed then that "an analogous approach [had been] taken by the Polish Constitutional Tribunal in its decision on the constitutionality of Poland's accession to the EU [...]" (para. 111).

46 Ústavni Soúd, PI. ÚS 29/09, Judgment of 3 November 2009 (Treaty of Lisbon II). For a comparison between the German and Czech Lisbon decisions, see Kramer, R. U., Looking through Different Glasses at the Lisbon Treaty: The German Constitutional Court and the Czech Constitutional Court, in: Fischer-Lescano, A., Joerges, C., Wonka, A., (eds.), 2010, The German Constitutional Court's Lisbon Ruling: Legal and Political-Science Perspectives, ZERP Discussion Paper no. 1, pp. 11-19. 
cannot delegate to the European Union. ${ }^{47}$ Similarly to the Conseil Constitutionnel, the Czech Constitutional Court is thereby keen on throwing the ball back into the political arena: ${ }^{48}$ the responsibility to curtail the European integration process lies first and foremost with the national Parliament, even though the door is left open for ex post judicial review of such decisions made on the political level.

Last but not least, one year later in its Lisbon ruling the Constitutional Tribunal of Poland outlined constitutional identity in terms of reflection of the values the domestic constitution is founded on. ${ }^{49}$ This notion encompasses, in particular, a prohibition to transfer the competence to confer competence (s.c. "Kompetenz-Kompetenz") to the EU in matters which constitute the fundamental basis of the political system. In this connection, it can be observed that the Trybunal Konstytucyjny essentially followed in the footsteps of the Lissabon-Urteil by providing a - still non-exhaustive - list of inalienable powers which lie at the heart of state sovereignty. ${ }^{50}$ On top of that, the Polish judges took a relevant step further, since they argued that national constitutional courts

"share, as a vital part of European constitutional traditions, the view that the constitutional judiciary plays a unique role as regards the protection of constitutional identity of the Member States, which at the same time determines the treaty identity of the European Union [...]" (para. III.3.8).

At a closer look, this statement paves the way for a twofold remark. The first one concerns the bold equivalence between the identity clause embedded in Article 4(2) TEU and the understanding(s) of national/ constitutional identity under construction in the legal frameworks of the

47 In this regard, the Court did not "consider it possible, in view of the position that it holds in the constitutional system of the Czech Republic, to create such a catalogue of non-transferrable powers and authoritatively determine 'substantive limits to the transfer of powers', as the petitioners request" (para. 111). In addition to the issue of transfer of national competences to the EU, the Ustavni Soúd openly objected also to the BVerfG's argument regarding the multi-levelled character of representative democracy (paras. 137-138).

48 Wendel, M., 2011, Lisbon before courts: comparative perspectives, European Constitutional Law Review, Vol. 7, Issue 1, p. 14.

49 Trybunal Konstytucyjny, Judgment K 32/09 of 24 November 2010, para. III.2.1.

50 Particularly, regardless of the difficulties related to setting a detailed catalogue of inalienable competences, the Polish Constitutional Court mentioned "decisions specifying the fundamental principles of the Constitution and decisions concerning the rights of the individual which determine the identity of the state, including, in particular, the requirement of protection of human dignity and constitutional rights, the principle of statehood, the principle of democratic governance, the principle of a state ruled by law, the principle of social justice, the principle of subsidiarity, as well as the requirement of ensuring better implementation of constitutional values and the prohibition to confer the power to amend the Constitution and the competence to determine competences". 
Member States. ${ }^{51}$ As concerns the second point of interest, it pertains the commonality among national constitutional jurisdictions invoked by the Trybunal Konstytucyjny. In this regard, when introducing a thorough assessment of the Lisbon case law of other constitutional courts, a previous passage of this judgment underlined that

"a common characteristic of those adjudications is the emphasis on the openness of the constitutional order to the European integration, and the focus on the significance of constitutional and systemic identity - and thus sovereignty - of the Member States" (para. III.3.1).

As a result, the Polish Constitutional Tribunal here stands as a sort of Janus Bifrons. As a matter of fact, its declared openness towards the European integration echoes, on the one side, the German Europarechtsfreundlichkeit of the Lissabon-Urteil. ${ }^{52}$ On the other side, the words of the Trybunal Konstytucyjny can be read as a kind of subtle call to arms for its foreign comrades, with the aim to point at a common front of resistance - this latter being united around the bulwark of national/constitutional identity - which defies the absolute primacy of EU law and its impact on the domestic legal systems. ${ }^{53}$

What can be inferred, in a nutshell, from the Lisbon jurisprudence we have recalled so far is the ever-growing circulation of the paradigm of constitutional identity across the "European" case law of national constitutional courts. There is little doubt that the identity clause, which was originally enshrined in the Constitutional Treaty and was later codified in Art. 4(2) TEU, has led constitutional identity to gain momentum as a key narrative of a new delicate stage of the European constitutionalism. Notwithstanding the unavoidable divergences between the specific attempts that each court makes in order to clarify the meaning and the (often blurred) contours of this notion, the common denominator which underlies the Lisbon case law of national jurisdictions is their assertion of the constitutional identity "untouchability" as a cornerstone of the European constitutionalization process.

51 Accordingly, in a previous passage of the decision the Trybunal emphasized that "an equivalent of the concept of constitutional identity in the primary EU law is the concept of national identity" (para. 2.1).

52 In the same vein, the Trybunal Konstytucyjny recognized a "favourable predisposition towards the process of EU integration", thus echoing the German Europarechtsfreundlichkeit (para. III.2.2).

53 Similarly, see Kowalik-Bańczyk, K., Sending smoke signals to Luxembourg: the Polish constitutional tribunal in dialogue with the ECJ, in: Claes, M., Visser, M. de, Popelier, P., Heyning, C. Van de (eds.), 2012, Constitutional conversations in Europe: actors, topics and procedures, Cambridge, Intersentia, p. 273. 
As someone has acutely observed, the Lisbon-related decisions seem to take the form of a strategic move meant to enhance the constitutional courts' role as arbiters and gatekeepers of the domestic validity and/ or enforcement of EU law, thus tightening their grip on the advancement of European integration. ${ }^{54}$ As it was noticed with reference to the Lissabon-Urteil, the emphasis that both the BVerfG and its foreign peers put on the "responsibility" of national parliaments towards the EU integration process may thus just be masking the fact that constitutional courts shall in any case retain the final word, inasmuch as they ultimately patrol the way the Member States' legislatures carry out their own duty. ${ }^{55}$ Against this backdrop, it is now possible to look at the post-Lisbon landscape, in order to explore how such increasing focus on identity review as a crucial avenue of constitutional resistance has brought back the threat of a recourse to the counter-limits.

\section{A Nuanced Attitude: The Courts' Dialogue as a Neutral Territory of Serious Constitutional Clashes?}

The question previously mentioned regarding the openness of national constitutional courts to accept the progress of the EU constitutional narrative finds some answers in a series of cases concerning possible violations of national constitutional identity.

First of all, it is important to start by saying that this analysis has a proper and sui generis legal environment, i.e. the use of the preliminary reference by the constitutional courts. As a matter of fact, the relationship between these latter and the European CJEU is no longer a remote dialogue since the domestic supreme courts decide to apply the procedure foreseen in Art. 267 TFEU. It is exactly this recent procedural evolution that brings to light a front of resistance to the EU constitutional narrative. From the procedural point of view, another common note underlying this front of resistance is a general attitude to build the rationale of the decision also on the different Member States' experiences, in order to strengthen the position of national constitutional courts before the CJEU. This judicial strategy is particularly clear in the Gauweiler case, when the Karlsruhe judge recalls that "a large majority of constitutional and supreme courts

54 Dyèvre, A., 2013, European Integration and National Courts: Defending Sovereignty under Institutional Constraints?, European Constitutional Law Review, Vol. 9, Issue 1, p. 139.

55 See Mayer, F. C., 2011, p. 762. 
of the other Member States shares the view of the Federal Constitutional Court that the precedence (of application) of Union law does not apply without limits, but that it is restricted by national (constitutional) law" (para. 140; likewise, $M r$. R. case, para. $47^{56}$ ), thus explicitly quoting a very long list of EU Member States' constitutional judgments on this issue. At the same time, it is not totally clear what kind of relevance these foreign cases may have on the specific matter at stake since, by and large, constitutional identity review has per se a case by case nature. In this sense, foreign precedents - and their possible dialogue undertaken with the CJEU - can be used as interpretative criteria by the constitutional courts, but cannot bind their judgments. After all, national constitutional courts consider their own concept of constitutional identity in an absolutely unique way, responsive to the constitutional traditions of that specific context.

\subsection{THE IDENTITY REVIEW IN GAUWEILER: TRIGGERING A TICKING BOMB?}

The abovementioned Gauweiler case represents the first occasion in which the German constitutional judge requests that the CJEU verifies a possible contrast between the EU regulation (more specifically the OMT

56 While the dialogue between the BVerfG and the CJEU was interestingly taking place, the BVerfG gave another landmark decision on constitutional identity review: BverfG, Case No. 2 BvR 2735/14 of 15 December 2015, Mr. R. This judgment is slightly different from the cases analyzed in this paper, since it pertains the realm of fundamental rights' protection, more precisely the possible violation of Art. 1 GG, i.e. the human dignity. The question at stake recalls clearly the issues debated in the already mentioned Melloni judgment and "read together, these cases address a powerful warning to the Court to avoid making excessive intrusion to the constitutional traditions in the area of fundamental rights protection" (Anagnostaras, G., 2017, Solange III? Fundamental Rights Protection under the National Identity Review, European Law Review, Vol. 42, No. 2, p. 245). This observation is important, since it conveys the message that constitutional identity review is necessarily a case judgment. Interestingly, in this case, the constitutional judge observes that its identity review "does not entail a substantial risk for the uniform application of Union law. On the one hand, violations of the principles of Art. $1 \mathrm{GG}$ in particular, which are at issue here, will only occur rarely - for the reason alone that Art. 6 TEU, the Charter of Fundamental Rights and the case-law of the Court of Justice of the European Union generally ensure an effective protection of fundamental rights vis-à-vis acts of institutions, bodies and agencies of the European Union [...]. On the other hand, the powers of review reserved to the Federal Constitutional Court are to be exercised with restraint and in a manner open to European law [...]. To the extent required, it will base its review of the European act in question on the interpretation of that act provided by the Court of Justice of the European Union in a preliminary ruling pursuant to Art. $267 \mathrm{sec} .3$ TFEU. This does not only apply in the context of the ultra vires review, but also applies to declaring inapplicable an act of an institution, body or agency of the European Union in Germany, because it affects the constitutional identity protected by Art. 79 sec. 3 in conjunction with Art. 1 and 20 GG [...]”. 
- "Outright Monetary Transactions" system) and the German constitutional identity. This complex legal saga passed first through the decision of the BVerfG to promote, with a ruling issued on January 14, 2014, its first order for reference to the CJEU. ${ }^{57}$ Lastly, the CJEU replied with the decision of June $2015^{58}$ and in 2016 the BVerfG closed the case. ${ }^{59}$

The BVerfG historic decision to make its first reference for a preliminary ruling followed the pathway announced in its previous decision Mangold/Honeywell. In the OMT case, in fact, the Federal Court essentially mitigated the harsh criteria set out in the Lissabon-Urteil and stated that counter-limits would represent just a residual option, being applicable only after having referred the question to the CJEU, which has always to be allowed to rule on the possible conflict and eventually to neutralize it in advance. ${ }^{60}$ If this judgment has been considered as a domesticated version of the previous Lissabon-Urteil, the reference for a preliminary ruling by the BVerfG was actually much less europarechtsfreundlich than expected. As a matter of fact, the Karlsruhe judges clearly highlighted that

"[...] the identity review performed by the Federal Constitutional Court is fundamentally different from the review under Art. 4 sec. 2 sentence 1 TEU by the Court of Justice of the European Union. Art. 4 sec. 2 sentence 1 TEU obliges the institutions of the European Union to respect national identities. This is based on a concept of national identity which does not

57 BVerfG, Case No. 2 BvR 2728/13 of 14 January 2014.

58 CJEU, Peter Gauweiler and Others v. Deutscher Bundestag, Case C-62/14, 16 June 2015.

59 BVerfG, Case No. 2 BvR 2728/13 of 21 June 2016.

60 BVerfG, Case No. 2 BvR 2661/06 of 6 July 2010, regarding a possible violation of competences (ultra vires act). See especially at paras. 58-60: "Ultra vires review may only be exercised in a manner which is open towards European law [...].

The Union understands itself as a legal community; it is in particular bound by the principle of conferral and by the fundamental rights, and it respects the constitutional identity of the Member States [...] According to the legal system of the Federal Republic of Germany, the primacy of application of Union law is to be recognised and it is to be guaranteed that the control powers which are constitutionally reserved for the Federal Constitutional Court are only exercised in a manner that is reserved and open towards European law.

[...] Prior to the acceptance of an ultra vires act on the part of the European bodies and institutions, the Court of Justice is therefore to be afforded the opportunity to interpret the Treaties, as well as to rule on the validity and interpretation of the legal acts in question, in the context of preliminary ruling proceedings according to Art. 267 TFEU. As long as the Court of Justice did not have an opportunity to rule on the questions of Union law which have arisen, the Federal Constitutional Court may not find any inapplicability of Union law for Germany." 
correspond to the concept of constitutional identity within the meaning of Art. 79 sec. 3 GG, but reaches far beyond [...]". 61

The clash between the two different interpretations of constitutional/national identity could not be more evident, and - at a closer look such difference was clear also with respect to the previous Lissabon-Urteil, where the two identity clauses were defined as going "hand in hand". 62

The word now passes to the CJEU: what does the judge sitting in Luxembourg reply to that BVerfG order?

First of all, even if many Member States asked the CJEU to dismiss the case as inadmissible since "the request already includes, intrinsically or conceptually, the possibility that it will in fact depart from the answer received" (Conclusions of Advocate General Bot, para. 36), the Luxembourg Court accepted the case on the ground of the principle of sincere cooperation (!). Moreover, the CJEU refrained from adopting the wellknown reasoning regarding the autonomy and primacy of EU law (also over the domestic constitutional law). Almost incidentally, it merely recalled that "a judgment which gives a preliminary ruling is binding on the national court, as regards the interpretation or the validity of the acts of the EU institutions in question, for the purposes of the decision to be given in the main proceedings". 63

The decision per se is strictly focused on substantive arguments regarding the OMT decision, showing that it falls within the European Central Bank (ECB) mandate and therefore cannot be considered ultra vires. In other words, instead of discussing ultimate authority in the European integration's constitutional design, the CJEU chooses the way of

61 BVerfG, Case No. 2 BvR 2728/13 of 14 January 2014, para. 29. In this respect, the BVerfG added that "the Court of Justice of the European Union treats the protection of national identity, which is required according to Art. 4 sec. 2 sentence 1 TEU, as a 'legitimate aim' which must be taken into account when legitimate interests are balanced against the rights conferred by Union law [...]. However, as an interest which may be balanced against others, the respect of national identity which is required according to Art. 4 sec. 2 sentence 1 TEU does not meet the requirements of the protection of the core content of the Basic Law according to Art. 79 sec. 3 GG, which may not be balanced against other legal interests. The protection of the latter is a task of the Federal Constitutional Court alone." Although it is not possible to discuss that here, it is worth recalling also the very interesting dissenting opinion on the issue of an identity review based on Art. 38 GG (for ultra vires acts).

62 Advocate General Bot - as we already mentioned at the end of para. 2 - points out very clearly that this is not a correct interpretation of relationship between the two legal orders on this matter at all, since the European integration progress reveals "a basic convergence between the constitutional identity of the Union and that of each of the Member States". As we already mentioned in this analysis, this crucial issue represents the battlefield of the European constitutionalism in the making.

63 CJEU, Peter Gauweiler and Others v. Deutscher Bundestag, Case C-62/14, para. 16. 
arguments strictly pertaining the specific issue at stake, partly accepting some of the interpretations suggested by the BVerfG's referral order. It goes without saying that this decision could be seen as a classic example of judicial restraint. ${ }^{64}$

The Bundesverfassungsgericht closes then this saga with the appearance of another "sentenza-manifesto politico" but the substance - at the end of the day - is one of a (more or less) successful agreement with the CJEU. ${ }^{65}$ More precisely, as regards the matter at issue, the BVerfG states that the OMT programme does not manifestly exceed the competences attributed to the ECB and does not manifestly violate the prohibition of monetary financing of the budget, if interpreted in accordance with the preliminary ruling of the CJEU. ${ }^{66}$

With regard to the debated issue concerning the difference between the identity review undertaken by the BVerfG and the national identity review foreseen in Art. 4(2) TEU, the Karlsruhe Court links - surprisingly enough, if we consider its 2015 referral order - its identity review to the respect of national identity as enshrined in the EU treaties. Particularly, the principle of loyal cooperation is the natural framework of this harmo-

64 In this context, it is not to understimate the fact the Karlsruhe Court has always had a leading position in the EU integration process. Pliakos, G., Anagnostaras, A., 2017, Saving Face? The German Federal Constitutional Court Decides Gauweiler, German Law Journal, Vol. 18, Issue 1, p. 230, pinpoint as well possible indirect effect of the OMT saga. Just a couple months before the follow up judgment of the FCC in Gauweiler, the CJEU gave an important decision in Aranyosi and Căldărau (Joined Cases C-404/15 and 659/15, Pál Aranyosi and Robert Căldărau v. Generalstaatsanwaltschaft Bremen, 5 April 2016), showing a milder version of the absolute principle of supremacy expressed in Melloni on the same issue at stake: "seen in this perspective, Aranyosi and Căldărau could very well be the outcome of an indirect judicial dialogue that took place in a particularly important and sensitive legal area that has been traditionally perceived as part of the core business of constitutional courts".

65 In the ruling of the German Constitutional Court the CJEU judgment is by no means exempt from explicit and at times harsh criticism, not addressed here since they deal with the merit of the OMT matters. Therefore, it has been observed that even if the Gauweiler case writes an important page of the "dialogue between Courts", yet a careful reading of the arguments shows how much that dialogue is anything but a polite conversation between gentlemen (Faraguna, P., 2016, La sentenza del Bundesverfassungsgericht sul caso OMT/Gauweiler, Diritti Comparati Working Paper, no. 1, p. 10).

66 It is important to underline that some applicants' claims are declared inadmissible, since they directly challenge an EU act. This issue puzzles the reader, considering its previous case law regarding the fundamental rights' protection of German citizen also in case of a possible violation deriving from an EU act (see Maastricht-Urteil, for example). Nonetheless, the Court maintains this task within the borders of its scrutiny as "preliminary questions" if the EU act represents the basis of a German rule or if they could trigger the responsibility of the State in front of the EU institutions. 
ny between these two clauses. ${ }^{67} \mathrm{~A}$ closer reading of this passage, though, could raise a doubt: is the German Court suggesting that Art. 4(2) TFEU allows a Member State to deviate from EU law when it considers that EU law runs against its national identity? ${ }^{28}$ The risk of this reading is quite obvious: it implies the possibility of unilaterally determining the meaning of Art. 4(2) TEU from the Member State's point of view and, as a consequence, of infringing the spirit of cooperation foreseen in Art. 4(3) TEU.

\subsection{THE IDENTITY REVIEW IN TARICCO: DEFUSING A TICKING BOMB?}

Alongside the BVerfG, also the Italian Constitutional Court takes active part in this kind of debate with the CJEU through the instrument of preliminary reference to the CJEU.

In particular, the Constitutional Court's referral order n. 24 of 26 January 2017 enriched the famous case Taricco with a further prominent step. This order is the second preliminary reference made by the Italian Corte Costituzionale in an incidental judicial review of constitutionality - after the previous referral order n. 207/2013 concerning school staff ${ }^{69}-$ and the

67 Ibid., para. 140: "As the Senate explained in detail in its Order of 15 December 2015 [...], the identity review does not violate the principle of sincere cooperation within the meaning of Art. 4 sec. 3 TEU. On the contrary, Art. 4 sec. 2 sentence 1 TEU essentially provides for identity review $[\ldots]$ and therefore it also conforms to the institutional situation of the European Union. The European Union is an association of sovereign states, of constitutions, administrations, and judiciaries [...] founded upon international treaties concluded between the Member States. As masters of the Treaties (Herren der Verträge), the Member States, by ordering the applicability of European law at the national level, decide whether and to what extent Union law may claim applicability and precedence within the respective Member State [...]."

68 Payandeh, M., 2017, The OMT Judgment of the German Federal Constitutional Court. Repositioning the Court within the European Constitutional Architecture, European Constitutional Law Review, Vol. 13, Issue 2, p. 415; Mayer, F. C., 2014, pp. 496-499.

69 In this case the Court analyzes Italian employment legislation which permitted various classes of supply teachers to be appointed under successive fixed-term contracts, without setting a limit on the total duration of such appointments or the number of renewals, and with no provision for the payment of damages in the event of their abuse. The Court held that the question as to whether the organisational requirements of the Italian school system constituted objective reasons within the meaning of Directive 1999/70/EC fell to be resolved by the CJEU, (along with other complementary issues). The CJEU, with the well-known Mascolo judgment (Joined Cases C-22/13, C-61/13, C-63/13, C-418/13, Raffaella Mascolo and Others v. Ministero dell'Istruzione, dell'Università e della Ricerca and Comune di Napoli, 26 November 2014), declared the Italian legislation inconsistent with EU law, to the extent that it lacked some specific criteria described in the judgment. In the meantime, however, 
first one in which a possible conflict with the supreme principles of the national constitutional order is evoked.

At stake there is the debated reading of the CJEU judgment Taricco (8 September 2015)..$^{70}$ The Supreme Court of Cassation and the Court of Appeal of Milan, in fact, considered that the rules established in the s.c. Taricco I decision contrasted with a number of supreme principles of the Italian constitutional order - above all the principle of legality in criminal matters, ex Art. 25 and Art. 101, 2 of the Italian Constitution and the general principle of legal certainty - and referred the case to the Constitutional Court which, in turn, asked for the intervention of the CJEU.

If the initiated dialogue seems at first sight to be the expression of a cooperative constitutionalism, then it unfolds in tones that end up overwhelming the Europeanist perspective. Without being able to enter into details of the case regarding a complex issue on VAT, it is enough to remember here that whenever both supranational and constitutional factors are at stake, the latter are invariably privileged, as a sign of a dualist perspective ultimately adopted by the Italian Constitutional Court.

Indeed, the sharp question that the Corte Costituzionale asked to the CJEU as to whether "the national courts should apply the rule even where it conflicts with a supreme principle of the Italian legal system" already receives a preventive and unequivocal answer in the affirmative within the referral order itself: in spite of CJEU's staunch defence of the primauté, Art. 4(2) TEU requires "to embrace the minimum level of diversity that is necessary in order to preserve the national identity inherent within the fundamental structure of the Member States" ${ }^{71}$

the Italian government - after the CJEU decision and before the intervention of the Constitutional Court - adopted a reform law (Law 13 July 2015, No. 107, c.d. "buona scuola") partly satisfying the requests expressed in the CJEU decision. Therefore, the following judgment of the Italian Constitutional Court was - if we can say so - easier, since the legislative framework was already changed: see judgment nr. 187/2016 (20 July 2016).

70 CJEU, Taricco I, Case C-105/14, 8 September 2015; in this ruling the Grand Chamber of the CJEU stated the obligation for the national court to disapply domestic regulation when - by setting certain criteria on the limitation period - it prevents the Italian State from fulfilling its obligations to effectively protect the financial interests of the Union imposed by Art. 325 of the TFEU (tax fraud).

71 It is not useless to recall here the entire argument of the Italian Constitutional Court on this issue: "According to Article 4(3) of the Treaty on European Union (TEU), [...] relations between the Union and the Member States are defined according to the principle of loyal cooperation, which implies mutual respect and assistance. This entails that the parties are united in diversity. There would be no respect if the requirements of unity were to demand the cancellation of the very core of values on which the Member State is founded. And there would also be no respect if the defence of diversity were to 
Even more sharply, with regard to the debated interpretation of Art. 4(2) TEU, the Constitutional Court observes that while the CJEU is entitled to define the scope of EU law, the requirement of assessing in detail whether this latter is compatible with the constitutional identity of each Member State has to be left to national authorities. As a matter of fact, the Court concludes - after having suggested in a very precise manner its reading of the issue at stake and a possible solution - by observing that "were this interpretation of Art. 325 TFEU and of the judgment given in the Taricco case to be correct, no grounds for contrast would remain and the question of constitutionality would not be upheld" (order n. 24/2017, para. 7). In other words: clear agreements, long friendship.

An authoritative scholar acutely noted that in this case the preliminary ruling - i.e. that institutionalised channel originally designed to foster a sincere and cooperative judicial dialogue - is transformed into a kind of ultimatum: EU law must be read in the light of the inalienable core of fundamental principles enshrined in the Italian constitution. This nucleus of fundamental principles, by the way, is quite extensive: it goes far beyond the common constitutional traditions, because it also protects the constitutional identity as a whole. We could have the impression of facing, therefore, a s.c. case of "primazia invertita" (reversed primacy). ${ }^{72}$ This special use of the preliminary ruling procedure by the domestic constitutional/supreme Courts represents ultimately a common thread in the European constitutional Courts' resistance front.

Be as it may, this frank dialogue with the CJEU could also end up in a more specific identification of the fundamental right at stake: in fact, with

extend beyond that core and end up hampering the construction of a peaceful future, based on common values, referred to in the preamble to the Nice Charter.

The primacy of EU law does not express a mere technical configuration of the system of national and supranational sources of law. It rather reflects the conviction that the objective of unity, within the context of a legal order that ensures peace and justice between nations, justifies the renunciation of areas of sovereignty, even if defined through constitutional law. At the same time, the legitimation for (Article 11 of the Italian Constitution) and the very force of unity within a legal order characterised by pluralism (Article $2 \mathrm{TEU}$ ) result from its capacity to embrace the minimum level of diversity that is necessary in order to preserve the national identity inherent within the fundamental structure of the Member State (Article 4(2) TEU). Otherwise, the European Treaties would seek, in a contradictory fashion, to undermine the very constitutional foundation out of which they were born by the wishes of the Member States." (order n. 24/2017, 26 January 2017, para. 6). Interestingly, the Court also specifies that the proposed interpretation is "to preserve the constitutional identity of the Republic of Italy" and it is not aimed at infringing the requirement of uniform application of EU law (ibid., para. 8).

72 Bernardi, A., 2017, La Corte costituzionale sul caso Taricco: tra dialogo cooperativo e controlimiti, Quaderni Costituzionali, 1, p. 112. 
the judgment M. A. S. ${ }^{73}$, the Luxembourg Court took in serious consideration the doubts raised by the Italian Constitutional Court and refined the reading of the debated issue. While confirming the obligation stemming from Art. 325 TFEU to take all necessary measures to protect the financial interests of the European Union (Taricco I), the CJEU appears concerned about ensuring that this obligation is achieved in the most respectful manner of the procedural autonomy of the Member State, read in light of that national identity being inherent in the fundamental constitutional structure. ${ }^{74} \mathrm{~A}$ direct effect of this stance is the strong emphasis on the necessity that it is up to the national legislator to establish the rules allowing to fulfill the obligations under Art. 325 TFEU (para. 41).

The CJEU has thus provided the Italian judges with the "most cooperative decision possible" 75 within the limits of compatibility with its own system, but it also carefully avoided entering into an in-depth - and thorny - debate as regards common constitutional traditions and the issue of constitutional identity. And sometimes silence is noisier than words.

Happily enough, on the $31^{\text {st }}$ of May 2018 the Corte Costituzionale easily closed the case stating that "the inapplicability of the 'Taricco rule, as recognized by the M. A. S. judgment, arises 'not only from the Italian Constitution but in Union law itself' and that the questions of constitutionality raised on the basis that the law was, instead, applicable, are unfounded." 76

While the judicial dialogue developed throughout the episodes of the Taricco saga can be read, at the end of the day, as an example of a fruitful (albeit sharp) interaction between the Italian judges and the CJEU, it is also useful to remind in our analysis other constitutional/supreme courts' decisions which, for many good reasons, "have been registered with some alarm". 77 We are here referring to the judgments given in 2012 by the Czech Constitutional Court (Holubec case) and in 2016 by the Danish Supreme Court (Ajos), both sharing the conclusion not to apply a CJEU judgment on the interpretation of EU rules. At the same time, some alarm

73 CJEU, M. A. S. and M. B., Case C-42/17, 5 December 2017.

74 More precisely, the obligation for national courts to disapply domestic legislation on limitation periods on the basis of the "Taricco rule", does not need to be met when it entails a violation of the principle of certainty of offences and punishments, because of the insufficient degree of certainty of the applicable law or of the retroactive application of a legal framework that envisages a harsher system of punishments than that in force at the time when the crime is committed.

75 On this point see Guastaferro, B., 2018, Derubricare i conflitti costituzionali per risolverli: sezionando il caso Taricco, Quaderni Costituzionali, 2, p. 451.

76 Corte Costituzionale, Judgment No. 115/2018, 31 May 2018.

77 Hofmann, A., 2018, Resistance against the Court of Justice of the European Union, International Journal of Law in Context, Vol. 14, special issue 2, p. 258. 
has also been raised, as we will see, by the decision n. 22/2016 of the Hungarian Constitutional Court, which carried out both ultra vires and identity review of EU law.

\section{The Latest Counter-Reactions: Chronicle of a Domino Effect}

In the aftermath of the entry into force of the Lisbon Treaty, alongside the aforesaid case law of the BVerfG and of the Italian Corte Costituzionale, a growing number of decisions witnesses a trend of wider horizontal circulation of the constitutional identity narrative in the jurisprudence of foreign constitutional/supreme courts. A first example is provided, in this regard, by the well-known 2012 Holubec judgment of the Czech Constitutional Court. ${ }^{78}$ On that occasion, the Ustavni Soúd concluded that a CJEU preliminary ruling granting to Slovak nationals the right to receive a supplementary pension payment on the same terms as Czech nationals was ultra vires. ${ }^{79}$ Regardless of the highly debated infringement of the principle of conferral of competences to the European Union, at a closer look it appears that Czech justices would actually deny the applicability of the Luxembourg Court decision also on the basis of the "abandonment" of one of the tenets underlying the domestic constitutional system, i.e. the principle audiatur et altera pars. ${ }^{80}$ Furthermore, while not delving into an overt identity review, the belligerent legal reasoning of the Ustavni Soúd

78 Ústavni Soúd, Decision Pl. ÚS 5/12 (Slovak Pensions) of 31 January 2012. An English translation is available at https://usoud.cz/en/decisions. For an in-depth analysis of the case see, ex multis, Komarek, J., 2012, Czech Constitutional Court Playing with Matches: the Czech Constitutional Court Declares a Judgment of the Court of Justice of the EU Ultra Vires; Judgment of 31 January 2012, Pl. ÚS 5/12, Slovak Pensions XVII, European Constitutional Law Review, Vol. 8, Issue 2, pp. 323-337; Zbiral, R., 2012, Czech Constitutional Court, judgment of 31 January 2012, Pl. ÚS 5/12. - A Legal revolution or negligible episode? Court of Justice decision proclaimed ultra vires, Common Market Law Review, Vol. 49, Issue 4, pp. 1475-1491; Bobek, M., 2014, Landtová, Holubec, and the Problem of an Uncooperative Court: Implications for the Preliminary Rulings Procedure, European Constitutional Law Review, Vol. 10, Issue 1, pp. 54-89; Kühn, Z., 2016, Ultra Vires Review and the Demise of Constitutional Pluralism: The Czecho-Slovak Pension Saga, and the Dangers of State Courts' Defiance of EU Law, Maastricht Journal of European and Comparative Law, Vol. 23, Issue 1, pp. 185-194.

79 With reference to CJEU, Marie Landtová v Česká správa socialního zabezpečení, Case C-399/09, 22 June 2011.

80 In this regard, it is useful to recall that the Ustavni Soúd, while failing to send a preliminary reference to the Luxembourg Court, complained that the CJEU had not heard its view before issuing its preliminary ruling. 
conveyed the expectation that the CJEU "would familiarize itself with the arguments that respected [...] the constitutional identity of the Czech Republic, which it draws from the common constitutional tradition with the Slovak Republic". ${ }^{81}$

A second - and equally famous - case of "disobedience" against a CJEU preliminary ruling on the interpretation of EU provisions can be identified in the 2016 Ajos judgment of the Supreme Court of Denmark (Højesteret). ${ }^{82}$ In stark contrast with the interpretation given by Luxembourg, ${ }^{83}$ the Danish judges found that an unwritten general principle of EU law - namely the prohibition of discrimination on grounds of age and the issue of its direct effect in disputes between private parties - must not take precedence over the principles of legal certainty and protection of legitimate expectations.

While much ink has been spilt mostly about the Højesteret's ultra vires declaration as concerns the horizontal direct effect of general principles, in this clash between the Danish Supreme Court and the CJEU we can ultimately grasp the signs of an identity-centred conflict. In other words,

81 Ústavni Soúd, Decision Pl. ÚS 5/12 (Slovak Pensions) of 31 January 2012, para. VII. In addition to its ground-breaking outcome, the decision at issue is also interesting from a comparative perspective, as the judicial reasoning of the Ustavni Soúd explicitly relies upon the Solange and the Maastricht jurisprudence of the BVerfG, thus showing the authoritativeness and the cross-border effects of the German constitutional case law.

82 Højesteret, DI acting for Ajos A/S vs. The estate left by A, Case No. 15/2014, Judgment of 6 December 2016. An English translation of the decision is available at www.supremecourt.dk. For a comment, see Rask Madsen, M., Palmer Olsen, H., Sadl, U., 2017, Legal Disintegration? The Ruling of the Danish Supreme Court in AJOS, (https:// verfassungsblog.de/legal-disintegration-the-ruling-of-the-danish-supreme-court-inajos/); Zaccaroni, G., 2017, Un'altra crepa nella diga del dialogo? La Corte Suprema danese rifiuta di dare applicazione ad un rinvio pregiudiziale della Corte di Giustizia, Quaderni Costituzionali, 1, pp. 155-158.

83 CJEU, Dansk Industri (on behalf of Ajos A/S) v. Estate of Karsten Eigil Rasmussen, Case C-441/14, 19 April 2016. The referring judges asked the CJEU whether the general principle of non-discrimination on grounds of age precluded Danish legislation which, under some conditions, deprived an employee of certain rights depending on his or her age. In its preliminary ruling, the CJEU explained that EU law precludes such domestic rules and the referring court was bound to interpret the Danish provisions in conformity with EU law; in any event, if a consistent interpretation were not possible, the Danish courts and tribunals would have had to set them aside. For an analysis of the case, see Krunke, H., Klinge, S., 2018, The Danish Ajos Case: the Missing Case from Maastricht and Lisbon, European Papers, Vol. 3, No. 1, pp. 157182; Gualco, E., Lourenço, L., 2016, "Clash of Titans". General Principles of EU Law: Balancing and Horizontal Direct Effect, European Papers, Vol. 1, No. 2, pp. 643-652; Pollicino, O., 2016, La Corte di giustizia riconosce l'efficacia diretta orizzontale dei principi generali ma non delle direttive, Quaderni Costituzionali, No. 3, pp. 597-599. 
a principle being considered as a distinctive character of the Danish constitutional order (legal certainty and the related protection of legitimate expectations of the individual) comes into direct collision with another principle (non-discrimination on the ground of age) that the CJEU case law, in its turn, places at the heart of an EU constitutional identity in the making. ${ }^{84}$ In fact, such confrontation leads to what can be construed as an ambivalent outcome: on the one hand, Ajos judgment stems from a judicial interaction with the CJEU - as it happened in Gauweiler as well as in the Taricco saga and unlike the Slovak Pensions case - by means of the preliminary reference procedure under Art. 267 TFEU; on the other hand, it is certainly true that through this decision the Danish Supreme Court joins an ever broader choir of constitutional jurisdictions which, in a more or less explicit way, resort to national/constitutional identity defence in order to set aside a preliminary ruling of the CJEU.

Another piece of this counter-reactions domino effect can also be detected in the judgment that the Hungarian Constitutional Court (Alkotmánybiróság) pronounced in November $2016,{ }^{85}$ objecting to and challenging the European Council's decision 2015/1601 on the relocation of asylum seekers among the EU Member States for the purpose of tackling the refugee crisis. ${ }^{86}$ In a nutshell, on that occasion the majority of the Hungarian Constitutional Court took the view that the transposal of the new quota system into the national legal order would be at variance with the fundamental rights and principles protected under the Fundamental Law of Hungary. Accordingly, the Alkotmánybiróság then structured its legal reasoning into a fundamental rights review and an ultra vires review, this latter being composed of a sovereignty and an identity control. ${ }^{87}$

84 Zaccaroni, G., 2018, Is the horizontal application of general principles ultra vires? Dialogue and conflict between supreme European courts in Dansk Industri, (https://www. federalismi.it/nv14/articolo-documento.cfm?Artid=36201). However, the CJEU case law has accepted that the principle of non-discrimination can be derogated by the fundamental principles embedded in the national constitutional orders. In this respect, in addition to the aforementioned $M$. A. S. and M. B. case we can also recall, by way of example, judgments C-208/09, Sayn-Wittgenstein, 22 December 2010 and C-438/14, Bogendorff von Wolffersdorff, 2 June 2016.

85 Alkotmánybíróság, Decision No. 22/2016 (XII.5.) AB of 30 November 2016. An English translation of the judgment is available at http://hunconcourt.hu/uploads/ sites/3/2017/11/en_22_2016.pdf.

86 Council Decision (EU) 2015/1601 of 22 September 2015 establishing provisional measures in the area of international protection for the benefit of Italy and Greece. The validity of that Council Decision was the subject-matter of Joined Cases C-643/15 and C-647/15, Slovakia and Hungary v. Council.

87 Very interesting on this topic is the reading of Halmai, G., 2017, The Hungarian National(ist) Constitutional Identity, Quaderni Costituzionali, 1, p. 152; see also Kele- 
Interestingly enough, in tune with the comparative strategy that we have already encountered in Gauweiler, the Hungarian ruling on the EU Council's refugee distribution and settlement decision made explicit reference to the relevant case law of a series of foreign supreme and constitutional courts as concerns the relationship between EU law and their domestic legal systems. ${ }^{88}$ At the end of such extensive overview including, among many others, the BVerfG's Solange jurisprudence, ${ }^{89}$ the Maastricht-Urteil and the Lissabon-Urteil, the Hungarian judges adamantly claimed their power to

"examine whether exercising competences on the basis of [...] the Fundamental Law results in the violation of human dignity, the essential content of any other fundamental right or the sovereignty (including the extent of the competences transferred by the State) and the constitutional self-identity of Hungary." (para. 46).

For the first time ever, the Hungarian Constitutional Court wields thus the sword of national constitutional identity, granting leeway to carry out an identity review of - and eventually set aside - EU law measures. As we have seen, what stands out as an unprecedented move for the Hungarian constitutional justice does actually follow in the footprints of other foreign jurisdictions, in particular the BVerfG, which have also started using more and more frequently the paradigm of constitutional identity in their Europe-related case law. While seeking to align with the case law of other European constitutional courts and to derive further legitimacy from their counter-reactions to the alleged invasion of EU law, the Hungarian judges let it be understood their (at least formal) openness to establish a judicial dialogue with Luxembourg: the constitutional identity defence rests

men, K., 2017, The Hungarian Constitutional Court and the concept of national identity, in Ianus, 15-16, pp. 23-33.

88 Alkotmánybíróság, Decision No. 22/2016 (XII.5.) AB of 30 November 2016, paras. $32-44$.

89 Ibid., para. 49. With specific regard to the fundamental rights review, the Hungarian Constitutional Court referred to the German Solange jurisprudence in order to acknowledge the adequacy of the level of fundamental rights protection guaranteed by EU law. In line with the BVerfG, the Hungarian decision at issue maintained, therefore, that it is entitled to ensure "ultima ratio protection of human dignity and the essential content of fundamental rights, and it must recognize that the joint exercise of competences under Article E) (2) of the Fundamental Law would not result in a violation of human dignity or the essential content of fundamental rights". Nevertheless, in his concurring opinion Judge Juhász pointed out that the reception of the Solange solution within the Hungarian legal context was poorly reasoned. Accordingly, in his concurring opinion Judge Stumpf criticised the judgment at hand for seeking to emulate the BVerfG's approach without providing due justification, however, on the grounds of the Fundamental Law of Hungary. 
on Art. 4(2) TEU as well as on an "informal cooperation with the CJEU based on the principles of equality and collegiality, with mutual respect to each other". 90

In spite of this proclaimed rationale of cooperation with the CJEU, we should not neglect, as several scholars have pointed out, the dark side of the decision at hand. In fact, the Alkotmánybiróság equated the notion of constitutional identity entrenched in Art. 4(2) TEU with Hungary's constitutional (self-) identity, the content thereof shall be construed from case to case on the basis of the whole Fundamental Law. ${ }^{91}$ In this respect, Halmai bluntly defined this manoeuvre as an "abuse of constitutional identity", i.e. a ruling that is "nothing but national constitutional parochialism, an attempt to abandon the common European constitutional whole"; ${ }^{2}$ in a similar vein, Kochenov and Bàrd argued that the Hungarian interpretation of constitutional identity is "so vague that it can be considered as an attempt at granting a carte blanche type of derogation to the executive and the legislative from Hungary's obligations under EU law"; ${ }^{93}$ likewise, Kelemen and Pech noted that the Court's reasoning made a selective use of comparative law in order "to justify nativist not to say xenophobic migration policy". ${ }^{4}$

Taking such remarks into account, especially in light of the present rule of law debate involving first of all Hungary and Poland, it is more than legitimate to wonder whether this new version of the counter-limits made in Budapest might henceforth be applied, under the guise of a (still

90 Ibid., paras. 62-63.

91 In the decision at hand, the Court did not provide an exhaustive list of constitutional identity sensitive matters. However, it mentioned some important components thereof, such as "freedoms, the division of powers, republic as the form of government, respect of autonomies under public law, the freedom of religion, exercising lawful authority, parliamentarism, the equality of rights, acknowledging judicial power, the protection of the nationalities living with us". Moreover, the Court added that "the protection of constitutional self-identity may be raised in the cases having an influence on the living conditions of the individuals, in particular their privacy protected by fundamental rights, on their personal and social security, and on their decision-making responsibility, and when Hungary's linguistic, historical and cultural traditions are affected" (ibid., paras. 64-66).

92 Halmai, G., 2018, Abuse of Constitutional Identity. The Hungarian Constitutional Court on Interpretation of Article E) (2) of the Fundamental Law, Review of Central and East European Law, Vol. 3, Issue 1, p. 41.

93 Kochenov, D., Bard, P., 2018, Rule of Law Crisis in the New Member States of the EU. The Pitfalls of Overemphasising Enforcement, RECONNECT Working Paper, 1, p. 12. Accordingly, Halmai, G., 2018, p. 25, argued that in its decision the Hungarian Constitutional Court "rubberstamped the government's constitutional identity defense".

94 Kelemen, R. D., Pech, L., 2018, Why autocrats love constitutional identity and constitutional pluralism: Lessons from Hungary and Poland, RECONNECT Working Paper, 2, pp. $14-15$. 
blurred) notion of constitutional identity, with the aim to bypass any act taken by EU bodies or institutions, such as the EU relocation plan, and to ultimately defy the European integration project at its very foundations. ${ }^{95}$ In this context, may have the Hungarian case law already started to go down the road of turning Art. 4(2) TEU - which requires the Union to respect the national (and constitutional) identity of its Member States into a political weapon capable to threaten the primacy of EU law itself? ${ }^{96}$ To what extent will the Magyar notion of constitutional identity currently in the making allow Hungary, borrowing the words of judge Stumpf, to remain in the European Union "club"? 97 Indeed, the relevance of such open issues is confirmed by the more recent case law of the Hungarian Constitutional Court, which keeps setting the protection of constitutional identity as a limit to European integration. ${ }^{98}$

Against this backdrop, the strained relations between the Luxembourg Court and the Alkotmánybiróság seem still far from being settled. On top of that, the CJEU's judgment of 2 April 2020 upheld the actions brought by the EU Commission against Hungary, as well as against Poland and the Czech Republic, for failure to comply with the temporary mechanism for the relocation of applicants for international protection and,

95 Curiously enough, as noted by Gabor Halmai, while the BVerfG's invocation of constitutional identity aims to promote higher standards than those required under EU law, the Hungarian cross-reference to foreign case law in the case at issue serves to lower the standards of fundamental rights protection. See Halmai, G., 2017, p. 154.

96 In this regard, Drinóczi, T., 2017, Hungarian Constitutional Court: The Limits of EU Law in the Hungarian Legal System, ICL Journal, Vol. 11, Issue 1, p. 149, identified a "vicious circle" regarding identity review.

97 Stumpf, I., 2017, The Hungarian Constitutional Court's Place in the Constitutional System of Hungary, (http://real.mtak.hu/80143/1/PSZ\%202017.\%20angol.szam_beliv_14.pdf), p. 254.

98 As a matter of fact, in the wake of the 2016 Hungarian judgment on the quota system, a similar approach can also be observed in a variety of other cases, such as two orders related to the Act on Higher Education and the Act on NGOs (2018), a ruling concerning the Agreement on a Unified Patent Court (2018), a decision regarding the Government's asylum procedures (2019) and, lastly, a decision on a land trade dispute (2020). See Alkotmánybiróság, Order No. 3199/2018 (VI. 21.) AB and Order No. 3198/2018 (VI. 21.) AB of 4 June 2018; Decision No. 9/2018 (VII. 9.) $\mathrm{AB}$ of 26 June 2018 on the interpretation of Article E) paragraphs (2) and (4), Article Q) paragraph (3) and Article 25 of the Fundamental Law; Decision No. 2/2019 (III. 5.) AB of 25 February 2019; Decision No. 11/2020 (VI. 3.) AB of 21 May 2020. In the two first mentioned cases of 2018, where the EU Commission had launched an infringement procedure against Hungary, the Constitutional Court suspended its proceedings while awaiting the CJEU's decision, in a spirit of judicial dialogue with the Luxembourg Court (on those cases, see Tribl, N., Sulyok, M., 2018, Constitutional law: Hungary (2018), European Review of Public Law, Vol. 30, No. 4, pp. 1248-1253). 
therefore, to fulfil their obligations under EU law. ${ }^{99}$ Even though in that specific circumstance the CJEU did not expressly bring up the issue of national constitutional identity - an argument behind which the three defendants had more or less overtly entrenched themselves,$-{ }^{100}$ it would be no surprise if such ruling, which follows strictly the earlier conclusions of Advocate General Sharpston, triggered further identity-based and/or ultra vires severe claims by the constitutional jurisdictions of the said Member States in the near future.

Going back to the very beginning of our analysis, we should not underestimate the disruptive echo that the BVerfG's PSPP decision pronounced in May 2020 may have outside Germany, with special regard to those Member States in Central and Eastern Europe being currently involved in the mentioned infringement proceedings. ${ }^{101}$ Taking due account of the authoritativeness of the BVerfG's case law among the European constitutional courts, ${ }^{102}$ it cannot be ruled out the risk that an ever-growing

99 CJEU, Commission v. Poland, Hungary and the Czech Republic, Joined Cases C-715/17, C-718/17 and C-719/17, 2 April 2020.

100 In particular, the Republic of Poland and Hungary submitted that they were entitled under Art. 72 TFEU, read in conjunction with Art. 4(2) TEU, which reserves to them exclusive competence for the maintenance of law and order and the safeguarding of internal security, to disapply their secondary legal obligations arising from Council Decision (EU) 2015/1523 and/or Council Decision (EU) 2015/1601. The Czech Republic, for its part, contended that, in order to counter the threats to public security posed by the relocation of persons with potential links to religious extremism, it should be ensured that each Member State of relocation is able to safeguard its internal security in accordance with Art. 4(2) TEU and, more specifically, Art. 72 TFEU. According to the CJEU, the defendant Member States can rely neither on their responsibilities concerning the "maintenance of law and order and the safeguarding of internal security" as reiterated by Article 72 TFEU, nor on the alleged malfunctioning of the relocation mechanism to avoid implementing that mechanism.

101 This possible scenario is also envisaged, among others, in Poiares Maduro, M., 2020; Avbelj, M., 2020; Wilkinson, M., 2020; Faraguna, P., 2020, Il Bundesverfassungsgericht dichiara ultra vires il Quantitative easing (con uno sguardo al Pandemic Emergency Purchase Programme), Forum di Quaderni Costituzionali, 2, pp. 312-313.

102 In an exemplary way, in Grabenwarter, C., 2014, The Cooperation of Constitutional Courts in Europe - Current Situation and Perspectives, General Report, XVIth Congress of the Conference of European Constitutional Courts, (https://venice.coe.int/ files/Bulletin/SpecBull-CECC-e.pdf), p. xxiv, it was observed that "Many national reports submitted by other constitutional courts [...] mention the German Federal Constitutional Court as the most frequently cited foreign constitutional court, regardless of regional or linguistic factors, especially in matters relating to fundamental rights". With regard to this matter see, in particular, Rideau, J., The Case-law of the Polish, Hungarian and Czech Constitutional Courts on National Identity and the "German Model", in: Saiz Arnaiz, A., Alcoberro Llivina, C., (eds.), 2013, National Constitutional Identity and European Integration, Cambridge, Antwerp, Portland, Intersentia, pp. 243-262. 
number of Eurosceptic constitutional/supreme jurisdictions would use the Karlsruhe's identity and ultra vires reviews ad libitum, whenever it comes to dealing with any sensitive topic that may be perceived as an encroachment on the sphere of national sovereignty.

The rise of such concerns about the damaging effects of a migration of the Second Senate's approach in the PSPP judgment is even more fuelled by the fact that the Weiss case carries with it a further degree of complexity in comparison to the past ultra vires declarations rendered, as we have seen, by the Czech Constitutional Court in Landtová and the Danish Supreme Court in Ajos. As a matter of fact, as Sarmiento perceptively noticed, in Weiss "the BVerfG is going well beyond its Czech and Danish counterparts, stepping into the shoes of the Luxembourg judge and directly reviewing the legality of an EU act in an area of exclusive EU competence". ${ }^{103}$ That being so, what would concretely happen if any constitutional/supreme Court in the other twenty-six Member States started walking on the same argumentative path undertaken by the BVerfG - not least, the possibility of launching new infringement procedures against them - is still to be seen. Yet, it seems difficult to deny that the political and constitutional impact of such a feared chain reaction could irreparably jeopardise the EU integration project at its foundations. And in that case, to recall once again the words of the CJEU president, a Member State calling into question the primacy of EU law and engaging in a unilateral course of action "shows disrespect towards the other Member States and their peoples that continue to honour the Treaties on a reciprocal basis". ${ }^{104}$

103 Sarmiento, D., 2020, An Infringement Action against Germany after its Constitutional Court's ruling in Weiss? The Long Term and the Short Term, (https://eulawlive.com/ op-ed-an-infringement-action-against-germany-after-its-constitutional-courts-ruling-in-weiss-the-long-term-and-the-short-term-by-daniel-sarmiento/). In this regard, Ziller observed that "Contrairement aux précédents des arrêts de la Cour constitutionnelle tchèque di 31 janvier 2012, Pl. ÚS 5/12 et de la Cour suprême Danoise dans l'affaire 15/2014, Ajos, qui n'avaient d'effet que dans des cas d'espèce à portée limitée(les pensions retraites des citoyens slovaques en République tchèque et l'application d'un principe général du droit de l'Union à des relations spécifiques entre personnes privées), l'arrêt du 5 mai a de graves conséquences systémiques sur le droit de l'Union et sur l'Union elle-même". Similarly, Poli recognized that "although other constitutional courts in Denmark and in the Czech Republic have challenged the Court of Justice's authority by declaring ultra vires one of its rulings, in the present case the BVerfG jeopardises the spirit of comity and loyal cooperation between a domestic court and the Court of Justice that inspired its decision in Honeywell and threatens the functioning of the euro area". See Ziller, J., 2020, Linsoutenable pesanteur du juge constitutionnel allemande a propos de l'arrêt de la deuxième chambre de la Cour constitutionnelle fédérale allemande du 5 mai 2020 concernant le programme PSPP de la Banque Centrale Européenne, (http://rivista.eurojus.it/wp-content/uploads/pdf/Ziller-CorteCost-tedesca-PSPP.pdf), p. 157 and Poli, S., 2020, p. 237.

104 Lenaerts, K., 2020. 


\section{Conclusions}

"There is a great disorder under heaven ...": is this situation excellent? The old saying - hinting at the idea that the disappearance of the old order offers the opportunity to build a new one - could probably be partly adapted to the present stage of the European integration process.

At the end of our analysis, what can first be inferred from the cases examined in this paper is that the identitarian discourse, after its wellknown "codification" into Article 4(2) TEU, has gained unquestionable centrality within both the domestic and the supranational jurisprudence over the last decade. In the post-Lisbon constitutional landscape, a number of activist constitutional/supreme Courts have not hesitated to carry out, as we have seen, their own identity review of EU law - even in its close connection with the ultra vires review - with ever-increasing ease and frequency.

Looking into this case law through the glasses of comparative analysis, it can be acknowledged that the migration of an identitarian vocabulary becomes part and parcel of the development of a common constitutional grammar which allows national constitutional/supreme Courts, on the one side, to interrelate with each other in a more systemic way; ${ }^{105}$ on the other side, this phenomenon contributes to add a prominent brick to the panoply of argumentative tools that each national jurisdiction could use (and, at times, even potentially misuse) in order to strengthen its own position in the relationships with the CJEU. By analyzing this phenomenon from a long-term perspective, we cannot avoid the impression of being faced with the realization of the initial idea of setting limits to EU integration or, better said, of drawing fundamental constitutional borders to EU law.

How can one evaluate this new step?

This recent case law highlights thus a growing tendency among domestic constitutional Courts to shape an idea of national constitutional identity that, as someone observed, emerges as a "counter-concept" to EU constitutional identity. ${ }^{106}$ From this point of view, it is also by virtue of such horizontal circulation of the constitutional identity discourse that we have witnessed what Lustig and Weiler define as a "third wave of

105 Ninatti, S., Pollicino, O., 2020, Identità costituzionale e (speciale) responsabilità delle Corti, Quaderni costituzionali, 1, p. 191.

106 Uitz, R., 2016, National Constitutional Identity in the European Constitutional Project: A Recipe for Exposing Cover Ups and Masquerades, (https://verfassungsblog. $\mathrm{de} /$ national-constitutional-identity-in-the-european-constitutional-project-a-recipe-for-exposing-cover-ups-and-masquerades/). 
judicial review" within national legal orders: ${ }^{107}$ that is to say, a stage of contemporary constitutionalism where the protection of national constitutional identity tends to prevail over international instances ${ }^{108}$ - or, said in positive terms, where the protection of national constitutional identity becomes part and parcel of a serious conversation aimed to build a new phase of the European integration.

Be as it may, in so doing, national constitutional jurisdictions prove to be ready to draw red lines to the European constitutionalization process whenever this latter touches upon fundamental constitutional issues. In this perspective, we can certainly read these cases - last but not least, the PSPP decision of the German Constitutional Court - as a possible setback to the progress of European integration.

At the same time, however, we could also look at this case-law in the perspective of a dialogue between Courts: after all, the domestic constitutional judges decided not to avoid confrontation with their supranational counterpart, by asking the CJEU to intervene through the preliminary reference procedure under Art. 267 TFEU. To a certain extent, they actually recognize that the existing multilevel judicial mechanism can be applied also to constitutional - and, more specifically, identity-based - conflicts. It is precisely by means of a mutual interaction on the matter of constitutional identity that Courts are able to give substance to and set the boundaries of the inherently fluid concepts of national constitutional identity and EU constitutional identity, in order to avert clashes between two opposite legal stances in the most critical conflicts, as indeed it occurred in the Taricco saga. In this view we have also to witness a strong convergence between constitutional courts in the way in which they deal with these ultimate conflicts: even if every court and every legal order in Europe has its own legal tradition, one can clearly perceive an underlying common trend in dealing with the constitutional identity grammar. This phenomenon occurs not just for reasons of reciprocal influence between legal orders belonging to the same European project, but rightly shows a serious reflection on constitutional law per se as the process of European integration moves forward. After all, from the very beginning of the EU

107 To be more precise, the Authors conceive this third wave as a response and a reaction to a first wave, which consists of a series of "constitutional revolutions" within the domestic legal orders, and a second wave, whose essence "was the acceptance of international legal norms as hierarchically superior and thus the basis for judicial review by national courts". See Lustig, D., Weiler, J. H. H., 2018, p. 315 etc.

108 In particular, the Authors argued that "Resistance of domestic jurisdictions to international norms is, of course, a common phenomenon across time and across jurisdictions [...] What we are noticing as part of the third wave is the introduction of a new strand of reasoning and justification which uses the vocabulary of 'identity"'. Ibid., p. 357. 
foundation the "measure" of openness to European and international law characterizing some constitutional clauses enacted after the Second World War was left intentionally unsolved. ${ }^{109}$

At the end of the day, the expression "constitutional resistance" is therefore referring to a double-edged sword: a kind of prism in which we can grasp lights and shadows of the European constitutionalism in its making.

A final remark with regard to the relations involving the judicial and the political powers within the Member States has to be made. It can be argued that the identity (alongside the ultra vires) review of EU law concurs to enhance the role of constitutional/supreme jurisdictions as primary actors of the European integration process. But are we really sure that the chosen constitutional setting - that is, of ultimate legal conflict debated in national constitutional Courts' rooms - is the best way to proceed forward along the path of European integration? Should the political arena, especially in a time in which the solidity of the integration progress appears more than ever under stress, leave the guidance thereof mostly in the hands of the constitutional jurisdictions and, as a consequence, of their ever-evolving case law?

In this context, it seems that a major risk would be not only to override the authority of the political subjects but, as the recent Weiss case demonstrates in an exemplary way, also to put them in an even tighter spot: choosing between loyalty to the domestic constitutional/supreme Court and compliance with the CJEU's case law. ${ }^{110}$ It is not by accident that this quandary eventually emerges to its full extent against the backdrop of the concept of constitutional identity, which by its nature lies at the heart and, in the meantime, stretches to the edge of the national legal order. Whether the situation is truly "excellent" in order to advance to a new phase of European integration or not - that is to say, whether this kind of conflicts in front of national constitutional judges will strengthen or weaken the Member States' openness to the European integration process - is a story still to be written.

109 For a first reading on this issue see Ninatti, S., Lidea di Europa nelle costituzioni del dopoguerra, in: Geninatti Satè, L., Luther, J., Mastropaolo, A., Tripodina, C., (eds.), 2019, Le età della Costituzione. 1848-1918, 1948-2018, Milano, Franco Angeli, pp. 123-146.

110 In this respect, in Poiares Maduro, M., 2020, the Author observed that the BVerfG's PSPP decision put German public organs "in the difficult position of having to choose between its constitutional and EU commitments". See also Bogdandy, A. von, Grabenwarter, C., Huber, P. M., 2015, Il diritto costituzionale nel diritto pubblico europeo. Lesempio della rete istituzionalizzata della giustizia costituzionale, Rivista Aic, 4, p. 16, where the Authors highlighted the constitutional Courts' duty of "dual loyalty" towards both their domestic legal framework and European public law. 


\section{BIBLIOGRAPHY}

1. Anagnostaras, G., 2017, Solange III? Fundamental Rights Protection under the National Identity Review, European Law Review, Vol. 42, No. 2.

2. Arcari, M., Ninatti, S., Exploring Counter-Constitutionalism: The Backlash Effect of Constitutional Vocabulary of the European Court of Justice and the European Court of Human Rights, paper presented at the GlobCon Scholars Workshop, Berlin, 5-6 July 2018, in: Chiti, E., Martino, A. di, Palombella, G., (eds.), Letà dell'interlegalità, work in progress.

3. Baquero Cruz, J., 2008, The Legacy of the Maastricht-Urteil and the Pluralist Movement, European Law Journal, Vol. 14, No. 4.

4. Bernardi, A., 2017, La Corte costituzionale sul caso Taricco: tra dialogo cooperativo e controlimiti, Quaderni Costituzionali, 1.

5. Bobek, M., 2014, Landtová, Holubec, and the Problem of an Uncooperative Court: Implications for the Preliminary Rulings Procedure, European Constitutional Law Review, Vol. 10, Issue 1.

6. Bogdandy, A. von, Grabenwarter, C., Huber, P. M., 2015, Il diritto costituzionale nel diritto pubblico europeo. Lesempio della rete istituzionalizzata della giustizia costituzionale, Rivista Aic, 4.

7. Cassese, S., 2009, L'Unione europea e il guinzaglio tedesco, Giornale di diritto amministrativo, 9.

8. Chiti, M. P., 2009, Am deutschen Volk, Giornale di diritto amministrativo, 9.

9. Claes, M., Reestman, J. H., 2015, The Protection of National Constitutional Identity and the Limits of European Integration at the Occasion of the Gauweiler Case, German Law Journal, Vol. 16, Issue 4.

10. Drinóczi, T., 2017, Hungarian Constitutional Court: The Limits of EU Law in the Hungarian Legal System, ICL Journal, Vol. 11, Issue 1.

11. Dyèvre, A., 2013, European Integration and National Courts: Defending Sovereignty under Institutional Constraints?, European Constitutional Law Review, Vol. 9, Issue 1.

12. Faraguna, P., 2016, La sentenza del Bundesverfassungsgericht sul caso OMT/Gauweiler, Diritti Comparati Working Paper, 1.

13. Faraguna, P., 2020, Il Bundesverfassungsgericht dichiara ultra vires il Quantitative easing (con uno sguardo al Pandemic Emergency Purchase Programme), Forum di Quaderni Costituzionali, 2.

14. Gualco, E., Lourenço, L., 2016, “Clash of Titans”. General Principles of EU Law: Balancing and Horizontal Direct Effect, European Papers, Vol. 1, No. 2.

15. Guastaferro, B., 2018, Derubricare i conflitti costituzionali per risolverli: sezionando il caso Taricco, Quaderni Costituzionali, 2.

16. Habermas, J., 2001, So, Why Does Europe Need a Constitution?, Florence, European University Institute, Robert Schuman Centre of Advanced Studies.

17. Halmai, G., 2017, The Hungarian National(ist) Constitutional Identity, Quaderni Costituzionali, 1.

18. Halmai, G., 2018, Abuse of Constitutional Identity. The Hungarian Constitutional Court on Interpretation of Article E) (2) of the Fundamental Law, Review of Central and East European Law, Vol. 3, Issue 1. 
19. Hofmann, A., 2018, Resistance against the Court of Justice of the European Union, International Journal of Law in Context, Vol. 14, special issue 2.

20. Kelemen, K., 2017, The Hungarian Constitutional Court and the concept of national identity, Ianus, 15-16.

21. Kelemen, R. D., Pech, L., 2018, Why autocrats love constitutional identity and constitutional pluralism: Lessons from Hungary and Poland, RECONNECT Working Paper, No. 2.

22. Kochenov, D., Bard, P., 2018, Rule of Law Crisis in the New Member States of the EU. The Pitfalls of Overemphasising Enforcement, RECONNECT Working Paper, No. 1.

23. Komarek, J., 2012, Czech Constitutional Court Playing with Matches: the Czech Constitutional Court Declares a Judgment of the Court of Justice of the EU Ultra Vires; Judgment of 31 January 2012, Pl. ÚS 5/12, Slovak Pensions XVII, European Constitutional Law Review, Vol. 8, Issue 2.

24. Kowalik-Bańczyk, K., Sending Smoke Signals to Luxembourg: the Polish Constitutional Tribunal in Dialogue with the ECJ, in: Claes, M., Visser, M. de, Popelier, P., Heyning, C. van de (eds.), 2012, Constitutional Conversations in Europe: Actors, Topics and Procedures, Cambridge, Intersentia.

25. Kramer, R. U., Looking through Different Glasses at the Lisbon Treaty: The German Constitutional Court and the Czech Constitutional Court, in: Fischer-Lescano, A., Joerges, C., Wonka, A., (eds.), 2010, The German Constitutional Court's Lisbon Ruling: Legal and Political-Science Perspectives, ZERP Discussion Paper no. 1.

26. Krunke, H., Klinge, S., 2018, The Danish Ajos Case: the Missing Case from Maastricht and Lisbon, European Papers, Vol. 3, No. 1.

27. Kühn, Z., 2016, Ultra Vires Review and the Demise of Constitutional Pluralism: The Czecho-Slovak Pension Saga, and the Dangers of State Courts' Defiance of EU Law, in Maastricht Journal of European and Comparative Law, Vol. 23, Issue 1.

28. La Pergola, A., Del Duca, P., 1985, Community Law and the Italian Constitution, American Journal of International Law, vol. 79, issue 3.

29. Lustig, D., Weiler, J. H. H., 2018, Judicial Review in the Contemporary World Retrospective and Prospective, International Journal of Constitutional Law, Vol. 16 , Issue 2.

30. Mayer, F. C., 2011, Rashomon in Karlsruhe: A reflection on democracy and identity in the European Union: The German Constitutional Court's Lisbon decision and the changing landscape of European constitutionalism, International Journal of Constitutional Law, Vol. 9, Issue 3-4.

31. Mayer, F. C., 2014, Rebels Without a Cause? A Critical Analysis of the German Constitutional Court's OMT Reference, German Law Journal, Vol. 15.

32. Ninatti, S., L'idea di Europa nelle costituzioni del dopoguerra, in: Geninatti Satè, L., Luther, J., Mastropaolo, A., Tripodina, C., (eds.), 2019, Le età della Costituzione. 1848-1918, 1948-2018, Milano, Franco Angeli.

33. Ninatti, S., Pollicino, O., 2020, Identità costituzionale e (speciale) responsabilità delle Corti, Quaderni costituzionali, 1.

34. Payandeh, M., 2017, The OMT Judgment of the German Federal Constitutional Court. Repositioning the Court within the European Constitutional Architecture, European Constitutional Law Review, Vol. 13, Issue 2. 
35. Pliakos, G., Anagnostaras, A., 2017, Saving Face? The German Federal Constitutional Court Decides Gauweiler, German Law Journal, Vol. 18, Issue 1.

36. Poiares Maduro, M., Grasso, G., 2009, Quale Europa dopo la sentenza della Corte costituzionale tedesca sul Trattato di Lisbona?, Diritto dell'Unione Europea, 2.

37. Pollicino, O., 2008, European Arrest Warrant and Constitutional Principles of the Member States: a Case Law-Based Outline in the Attempt to Strike the Right Balance between Interacting Legal Systems, German Law Journal, Vol. 9, No. 1.

38. Pollicino, O., 2016, La Corte di giustizia riconosce l'efficacia diretta orizzontale dei principi generali ma non delle direttive, Quaderni Costituzionali, 3.

39. Reestman, J. H., 2009, The Franco-German Constitutional Divide: Reflection on National and Constitutional Identity, European Constitutional Law Review, Vol. 5, Issue 3.

40. Rideau, J., The Case-law of the Polish, Hungarian and Czech Constitutional Courts on National Identity and the "German Model", in: Saiz Arnaiz, A., Alcoberro Llivina, C., (eds.), 2013, National Constitutional Identity and European Integration, Cambridge - Antwerp- Portland, Intersentia.

41. Sadurski, W., Constitutional Justice, East and West: Introduction, in: Sadurski, W., 2002, Constitutional Justice, East and West: Democratic Legitimacy and Constitutional Courts in Post-Communist Europe in a Comparative Perspective, The Hague, Kluwer.

42. Schmid, C., 2001, All Bark and No Bite: Notes on the Federal Constitutional Court's "Banana Decision", European Law Journal, Vol. 7, No. 1.

43. Tribl, N., Sulyok, M., 2018, Constitutional law: Hungary (2018), European Review of Public Law, Vol. 30, No. 4.

44. Vranes, E., 2013, Constitutional Foundation of, and Limitation to, Integration in France, European Public Law, Vol. 17, No. 3.

45. Wendel, M., 2011, Lisbon Before Courts: Comparative Perspectives, European Constitutional Law Review, Vol. 7, Issue 1.

46. Zaccaroni, G., 2017, Un'altra crepa nella diga del dialogo? La Corte Suprema danese rifiuta di dare applicazione ad un rinvio pregiudiziale della Corte di Giustizia, Quaderni Costituzionali, 1.

47. Zbiral, R., 2012, Czech Constitutional Court, judgment of 31 January 2012, Pl. ÚS 5/12. - A Legal revolution or negligible episode? Court of Justice decision proclaimed ultra vires, Common Market Law Review, Vol. 49, Issue 4.

\section{LEgislative Sources}

1. Commission Regulation (EC) No 1972/2003 of 10 November 2003 on transitional measures to be adopted in respect of trade in agricultural products on account of the accession of the Czech Republic, Estonia, Cyprus, Latvia, Lithuania, Hungary, Malta, Poland, Slovenia and Slovakia.

2. Commission Regulation (EC) No 60/2004 of 14 January 2004 laying down transitional measures in the sugar sector by reason of the accession of the Czech Republic, Estonia, Cyprus, Latvia, Lithuania, Hungary, Malta, Poland, Slovenia and Slovakia. 
3. Council Decision (EU) 2015/1601 of 22 September 2015 establishing provisional measures in the area of international protection for the benefit of Italy and Greece.

\section{CAse LaW}

1. CJEU, Société Arcelor Atlantique et Lorraine and Others v. Premier ministre, Ministre de l'Ecologie et du Développement durable and Ministre de l'Economie, des Finances et de l'Industrie, Case C-127/07, Opinion of Advocate General Poiares Maduro, 21 May 2008.

2. CJEU, Ilonka Sayn-Wittgenstein v. Landeshauptmann von Wien, Case C-208/09, 22 December 2010.

3. CJEU, Marie Landtová v. Česká správa socialního zabezpečení, Case C-399/09, 22 June 2011.

4. CJEU, Stefano Melloni v. Ministerio Fiscal, Case C-399/11, Opinion of Advocate General Bot, 2 October 2012.

5. CJEU, Stefano Melloni v. Ministerio Fiscal, Case C-399/11, 26 February 2013.

6. CJEU, Raffaella Mascolo and Others v. Ministero dell'Istruzione, dell'Università e della Ricerca and Comune di Napoli, Joined Cases C-22/13, C-61/13, C-63/13, C-418/13, 26 November 2014.

7. CJEU, Peter Gauweiler and Others v. Deutscher Bundestag, Case C-62/14, Opinion of Advocate General Cruz Villalón, 14 January 2015.

8. CJEU, Peter Gauweiler and Others v. Deutscher Bundestag, Case C-62/14, 16 June 2015.

9. CJEU, Taricco and Others, Case C-105/14, 8 September 2015.

10. CJEU, Pál Aranyosi and Robert Căldărau v. Generalstaatsanwaltschaft Bremen, Joined Cases C-404/15 and 659/15, 5 April 2016.

11. CJEU, Dansk Industri (on behalf of Ajos A/S) v. Estate of Karsten Eigil Rasmussen, Case C-441/14, 19 April 2016.

12. CJEU, Nabiel Peter Bogendorff von Wolffersdorff v. Standesamt der Stadt Karlsruhe and Zentraler Juristischer Dienst der Stadt Karlsruhe, Case C-438/14, 2 June 2016.

13. CJEU, M. A. S. and M. B., Case C-42/17, 5 December 2017.

14. CJEU, Commission v. Poland, Hungary and the Czech Republic, Joined Cases C-715/17, C-718/17 and C-719/17, 2 April 2020.

15. Constitutional Council of France, 2004-505 DC, 19 November 2004.

16. Constitutional Council of France, 2006-540 DC, 27 June 2006.

17. Constitutional Council of France, 2007-560, 20 December 2007.

18. Constitutional Court of Austria, SV 2/08, G 80/08, 30 September 2008.

19. Constitutional Court of Hungary, AB 17/04, 25 May 2005.

20. Constitutional Court of Hungary, 143/2010 (VII. 14.), 12 July 2010.

21. Constitutional Court of Hungary, 22/2016 (XII.5.) AB, 30 November 2016.

22. Constitutional Court of Hungary, 3198/2018 (VI. 21.) AB, 4 June 2018. 
23. Constitutional Court of Hungary, 3199/2018 (VI. 21.) AB, 4 June 2018.

24. Constitutional Court of Hungary, 9/2018 (VII. 9.) AB, 26 June 2018.

25. Constitutional Court of Hungary, 2/2019 (III. 5.) AB, 25 February 2019.

26. Constitutional Court of Hungary, 11/2020 (VI. 3.) AB, 21 May 2020.

27. Constitutional Court of Italy, 183/1973, 18 December 1973.

28. Constitutional Court of Italy, 24/2017, 23 November 2016.

29. Constitutional Court of Italy, 115/2018, 31 May 2018.

30. Constitutional Court of Latvia, 2008-35-01, 7 April 2009.

31. Constitutional Court of Spain, 1/2004, 13 December 2004.

32. Constitutional Tribunal of Poland, P 1/05, 27 April 2005.

33. Constitutional Tribunal of Poland, K 18/04, 11 May 2005.

34. Constitutional Tribunal of Poland, K 32/09, 24 November 2010.

35. Constitutional Court of the Czech Republic, Pl. ÚS 50/04, 8 March 2006.

36. Constitutional Court of the Czech Republic, PI. ÚS 19/08, 26 November 2008.

37. Constitutional Court of the Czech Republic, PI. ÚS 29/09, 3 November 2009.

38. Constitutional Court of the Czech Republic, Pl. ÚS 5/12, 31 January 2012.

39. Federal Constitutional Court of Germany, 2 BvL 52/71, 29 May 1974.

40. Federal Constitutional Court of Germany, 2 BvR 197/83, 22 October 1986.

41. Federal Constitutional Court of Germany, 2 BvE 2/08, 2 BvE 5/08, 2 BvR 1010/08, 2 BvR 1022/08, 2 BvR 1259/08, 2 BvR 182/09, 30 June 2009.

42. Federal Constitutional Court of Germany, 2 BvR 2661/06, 6 July 2010.

43. Federal Constitutional Court of Germany, 2 BvR 2728/13, 14 January 2014.

44. Federal Constitutional Court of Germany, 2 BvR 2735/14, 15 December 2015.

45. Federal Constitutional Court of Germany, 2 BvR 2728/13, 21 June 2016.

46. Federal Constitutional Court of Germany, 2 BvR 859/15, 2 BvR 980/16, 2 BvR 2006/15, 2 BvR 1651/15, 5 May 2020.

47. Supreme Court of Denmark, 15/2014, 6 December 2016.

\section{INTERNET SOURCES}

1. Avbelj, M., 2020, The Right Question about the FCC Ultra Vires Decision, (https:// verfassungsblog.de/the-right-question-about-the-fcc-ultra-vires-decision/).

2. Caravita, B., Condinanzi, M., Morrone, A., Poggi, A. M., 2020, Karlsruhe: a wrong decision in a difficult political phase, (https://federalismi.it/nv14/articolo-documento.cfm?hpsez=Primo_Piano\&content=Karlsruhe:-a-wrong-decision-in-a-difficult-political-phase\&content_auth $=\% 253 \mathrm{Cb} \% 253 \mathrm{~EB}$.-Caravita,-M.-Condinanzi,-A.-Morrone,-A.-Poggi\%253C/b\%253E\&Artid=43527).

3. Dyevre, A., 2020, How Europe's Legal Equilibrium Unravelled, (https://ejiltalk.org/ how-europes-legal-equilibrium-unravelled/).

4. Eleftheriadis, P., 2020, Germany's Failing Court (www. https://verfassungsblog.de/ germanys-failing-court/). 
5. Garner, O., 2020, Squaring the PSPP Circle, (https://verfassungsblog.de/squaringthe-pspp-circle/).

6. Grabenwarter, C., 2014, The Cooperation of Constitutional Courts in Europe Current Situation and Perspectives, General Report, XVIth Congress of the Conference of European Constitutional Courts, (https:/venice.coe.int/files/Bulletin/ SpecBull-CECC-e.pdf).

7. Lenaerts, K., 2020, No Member State is More Equal than Others. The Primacy of EU law and the Principle of the Equality of the Member States before the Treaties, (https://verfassungsblog.de/no-member-state-is-more-equal-than-others/).

8. Marzal, T., 2020, Is the BVerfG PSPP decision "simply not comprehensible"?, (https://verfassungsblog.de/is-the-bverfg-pspp-decision-simply-not-comprehensible/).

9. Poiares Maduro, M., 2020, Some Preliminary Remarks on the PSPP Decision of the German Constitutional Court, (https://verfassungsblog.de/some-preliminary-remarks-on-the-pspp-decision-of-the-german-constitutional-court/).

10. Poli, S., 2020, The German Federal Court and its first ultra vires review: a critique and a preliminary assessment of its consequences, (http://rivista.eurojus.it/the-german-federal-court-and-its-first-ultra-vires-review-a-critique-and-a-preliminaryassessment-of-its-consequences/).

11. Rask Madsen, M., Palmer Olsen, H., Sadl, U., 2017, Legal Disintegration? The Ruling of the Danish Supreme Court in AJOS, (https://verfassungsblog.de/legal-disintegration-the-ruling-of-the-danish-supreme-court-in-ajos/).

12. Sarmiento, D., 2020, An Infringement Action against Germany after its Constitutional Court's ruling in Weiss? The Long Term and the Short Term, (https://eulawlive.com/op-ed-an-infringement-action-against-germany-after-its-constitutionalcourts-ruling-in-weiss-the-long-term-and-the-short-term-by-daniel-sarmiento/).

13. Stumpf, I., 2017, The Hungarian Constitutional Court's Place in the Constitutional System of Hungary, (http://real.mtak.hu/80143/1/PSZ\%202017.\%20angol.szam_ beliv_14.pdf).

14. Uitz, R., 2016, National Constitutional Identity in the European Constitutional Project: A Recipe for Exposing Cover Ups and Masquerades, (https://verfassungsblog. $\mathrm{de} /$ national-constitutional-identity-in-the-european-constitutional-project-a-recipe-for-exposing-cover-ups-and-masquerades/).

15. Wilkinson, M., 2020, Fight, flight or fudge?, (https://verfassungsblog.de/fightflight-or-fudge/).

16. Zaccaroni, G., 2018, Is the horizontal application of general principles ultra vires? Dialogue and conflict between supreme European courts in Dansk Industri, (https:// www.federalismi.it/nv14/articolo-documento.cfm?Artid=36201).

17. Ziller, J., 2020, L'insoutenable pesanteur du juge constitutionnel allemande A propos de l'arrêt de la deuxième chambre de la Cour constitutionnelle fédérale allemande du 5 mai 2020 concernant le programme PSPP de la Banque Centrale Européenne, (http://rivista.eurojus.it/wp-content/uploads/pdf/Ziller-CorteCost-tedesca-PSPP. pdf). 


\title{
USTAVNI OTPOR PRAVU EVROPSKE UNIJE: USTAVNI SUDOVI I TEST SUKOBA USTAVNOG IDENTITETA
}

\author{
Marco Galimberti, Stefania Ninatti
}

REZIME

Novija praksa ustavnih sudova država članica Evropske unije, koja se tiče sukoba ustavnog identiteta unutar Evropske unije, naglasila je snažno približavanje nacionalnih ustavnih sudova u načinu na koji tretiraju te sukobe: čak i ako se pođe od toga da svaki sud i svaki pravni poredak u Evropi ima svoju pravnu tradiciju, zajednički trend u tretiranju ustavnog identiteta jasno je uočljiv. Cilj ovog rada je da ukaže na sve veći intenzitet otpora ustavnih sudova pravu Evropske unije i proceni ustavne implikacije tog otpora na proces evropskih integracija.

$\mathrm{U}$ radu se prvo analizira preliminarno pitanje pojave ustavnih narativa u procesu evropskih integracija. Ukazuje se da su ustavne tradicije i ustavni identiteti država članica gotovo prirodno zauzeli središnje mesto u evropskim integracijama, u nekim slučajevima kao njihov sastavni element, a drugim kao pandan tekućem napretku tog procesa. Da bi se analizirale ustavne komponente sistema EU, prvo se razmatra postepeni razvoj koncepta „ustavne tradicije zajedničke državama članicama“ i koncepta „ustavnog identiteta“, kao osnovnih elemenata čitavog evropskog konstitutivnog procesa, zaključno sa uključivanjem posebne odredbe koja govori o nacionalnom identitetu država članica u Ugovor iz Lisabona (član 4, stav 2. Ugovora o Evropskoj uniji). Potom se razmatraju relevantni odgovori ustavnih/vrhovnih sudova iz uporedne perspektive, odnosno njihova praksa koja se tiče „rezerve ustavnog identiteta“, uključujući i praksu kontrole akata EU na osnovu „ultra vires“ doktrine, sa ciljem da se utvrde obrasci ustavnog otpora koji se mogu identifikovati u procesu evropskih integracija.

Posebna pažnja u ovom radu poklanja se odluci Saveznog Ustavnog suda Nemačke donetoj 2020. godine u predmetu PSPP, koja predstavlja vrhunac narativnog otpora ustavnih sudova pravu EU, a kojom je ovaj sud ustanovio da je Sud pravde Evropske unije, odlukom u predmetu programa javnih nabavki Evropske centralne banke, prekoračio nadležnost Evropske unije. Time se pokazuje da su nacionalni ustavni sudovi spremni da povuku crvene linije evropskom procesu konstitucionalizacije kad god se on dotakne osnovnih ustavnih pitanja. Zbog toga se na praksu ustavnih sudova može gledati kao na zastoj u napretku evropskih integracija.

Međutim, praksa ustavnih sudova može se posmatrati i u perspektivi dijaloga između sudova: na kraju krajeva, nacionalne ustavne sudije od- 
lučile su da ne izbegavaju konfrontaciju sa svojim nadnacionalnim kolegama, tražeći od Suda pravde EU da interveniše kroz prethodni postupak iz člana 267. Ugovora o funkcionisanju Evropske unije. U određenoj meri zapravo su prepoznali da se postojeći višestepeni sudski postupak može primeniti i na ustavne sporove, tačnije, na sukobe zasnovane na ustavnom identitetu. Upravo uzajamnom interakcijom po pitanju ustavnog identiteta, sudovi određuju suštinu i postavljaju granice fluidnim konceptima nacionalnog ustavnog identiteta i ustavnog identiteta EU, kako bi se izbegli sukobi u najkritičnijim slučajevima između dva suprotna stava u pravnoj teoriji.

Izraz „ustavni otpor" koji se koristi u ovom radu, dakle, odnosi se na mač sa dve oštrice, odnosno na neku vrstu prizme kroz koju možemo sagledati pozitivne i negativne strane razvoja evropskog konstitucionalizma.

Ključne reči: ustavni identitet, ustavni sudovi, evropski konstitucionalizam, evropske integracije, ustavni otpor.

Article History:

Received: 16 October 2020

Accepted: 25 November 2020 